\title{
Structural Geology and Tectonics of the Orville Coast Region, Southern Antarctic Peninsula, Antarctica
}

Work done in cooperation with the National Science Foundation
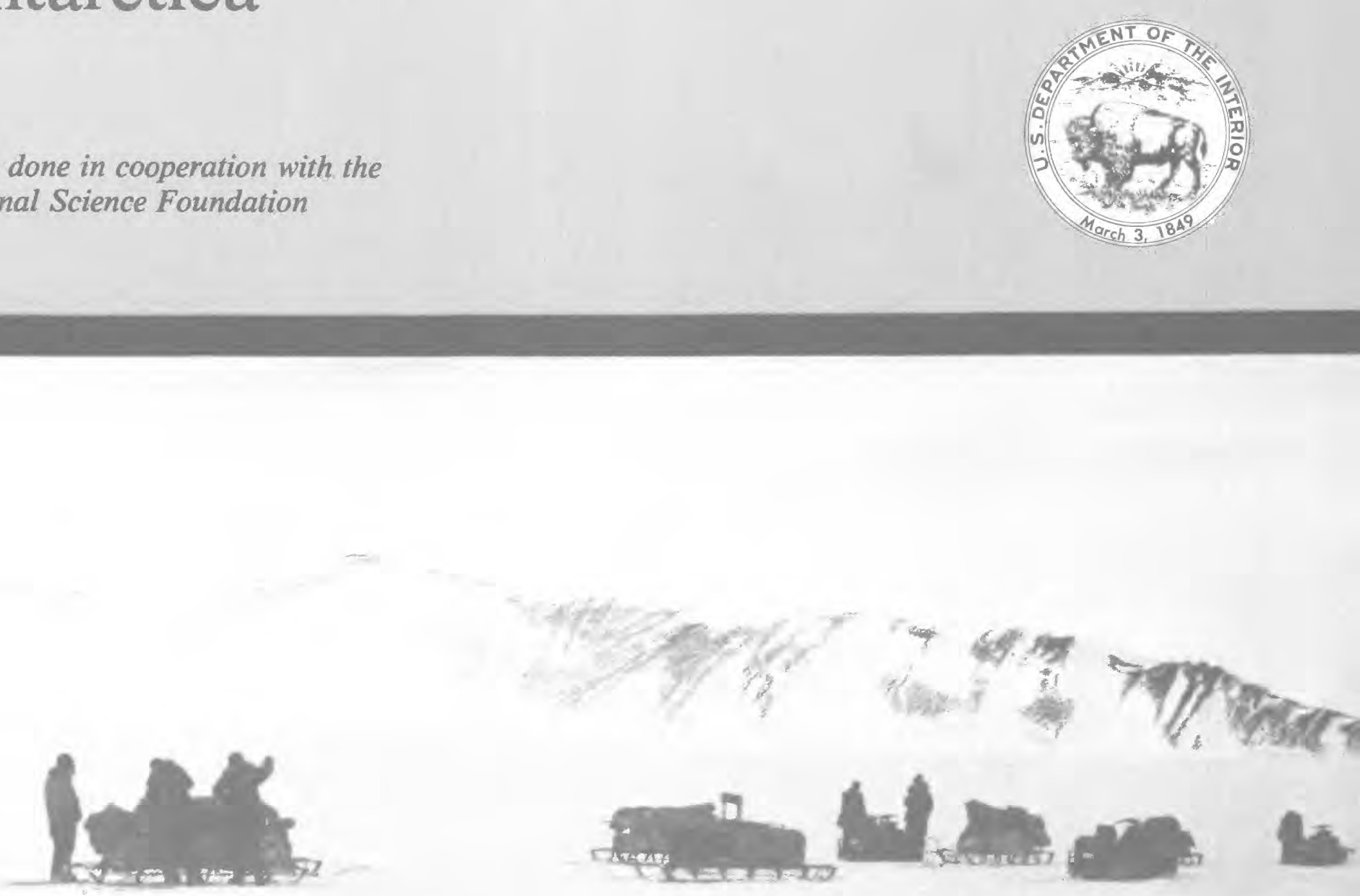
COVER-View to the northeast of chevron folds in the Latady Formation along a north-trending ridge in the northern Hauberg Mountains, $34 \mathrm{~km}$ east of Janke Nunatak. Pronounced southerly vergence is visible. Length of ridge is about $5 \mathrm{~km}$. 


\section{Structural Geology and Tectonics of the Orville Coast Region, Southern Antarctic Peninsula, Antarctica}

By KARL S. KELLOGG and PETER D. ROWLEY

U.S. GEOLOGICAL SURVEY PROFESIONAL PAPER 1498

Work done in cooperation with the National Science Foundation

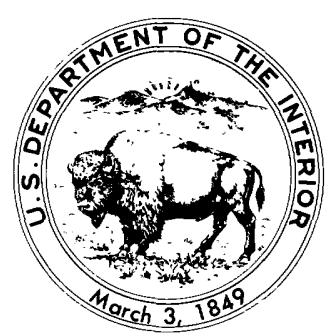




\section{DEPARTMENT OF THE INTERIOR}

MANUEL LUJAN, JR., Secretary

\section{U.S. GEOLOGICAL SURVEY}

Dallas L. Peck, Director

Any use of trade, product, industry, or firm names in this publication is for descriptive purposes only and does not imply endorsement by the U.S. Government

Library of Congress Cataloging-in-Publication Data

Kellogg, Karl S.

Structural geology and tectonics of the Orville Coast region, southern Antarctic Peninsula, Antarctica

(U.S. Geological Survey professional paper ; 1498)

Bibliography: p.

Supt. of Docs. no.: I 19.16:1498

1. Geology, Structural. 2. Geology-Antarctic regions-Orville Coast Region. I. Rowley, Peter D. II. National Science Foundation (U.S.) III. Title. IV. Series. QE601.K367 1989

88-607945

For sale by the Books and Open-File Reports Section, U.S. Geological Survey Federal Center, Box 25425, Denver, CO 80225 


\section{CONTENTS}

\begin{abstract}
Introduction

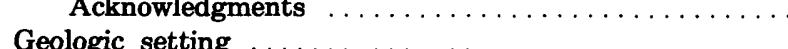

Structural geology

Structures of the Latady and Mount Poster Formations

Folds ............................

Axial-plane cleavage $\ldots \ldots \ldots \ldots \ldots \ldots \ldots \ldots$

Thrust faults $\ldots \ldots \ldots \ldots \ldots \ldots \ldots \ldots \ldots \ldots$

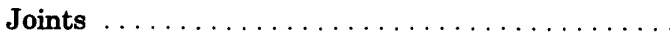

Quartz-filled fractures in sedimentary rocks .....

Structures of the Lassiter Coast Intrusive Suite .... Joints

Dikes
\end{abstract}

\begin{tabular}{r|} 
Page \\
1 \\
1 \\
3 \\
3 \\
6 \\
6 \\
6 \\
8 \\
8 \\
8 \\
9 \\
12 \\
12 \\
13
\end{tabular}

Structural geology-Continued High-angle faults

Paleomagnetic evidence for relative..... in the Sweeney and Hauberg Mountains

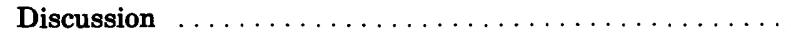

The Latady basin as a back-arc rift $\ldots \ldots \ldots \ldots \ldots$

Opening of the Weddell Sea $\ldots \ldots \ldots \ldots \ldots \ldots \ldots$

Origin of the Palmer Land deformational event ......

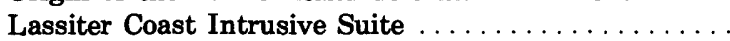

Southern tectonic boundary of the Orville Coast ....

Tertiary extension: Uplift, block faulting, and alkalic volcanism $\ldots \ldots \ldots \ldots \ldots \ldots \ldots \ldots \ldots \ldots$

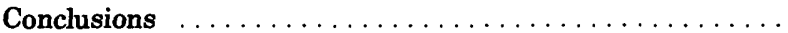

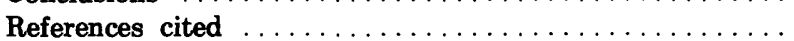

Page

13

14

18

18

19

21

22

22

23

\section{ILLUSTRATIONS}

FIGURE 1. Index map of part of West Antarctica showing major geographic features discussed in text $\ldots \ldots \ldots \ldots \ldots \ldots \ldots$

2. Sketch map of Antarctica showing proposed continental crustal blocks of West Antarctica $\ldots \ldots \ldots \ldots \ldots \ldots$

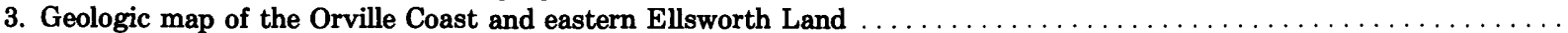

4. Chart showing geologic and tectonic events for the Orville Coast region $\ldots \ldots \ldots \ldots \ldots \ldots \ldots \ldots \ldots$

5-8. Photographs of folds in the Latady Formation:

5. Prominent anticline and syncline on west face of $\mathbf{M t}$. Dewe, eastern Hauberg Mountains . . . . . . . . . . .

6. Chevron folds along a ridge $\mathbf{2 8} \mathbf{~ k m}$ east of Janke Nunatak, northwestern Hauberg Mountains . . . . . . . . .

7. Tight folds on northern part of ridge that contains Mt. Dewe, eastern Hauberg Mountains .............

8. Tight recumbent syncline cut by high-angle apparent normal faults on flank of $\mathrm{Mt}$. Leek, northeastern Hauberg Moun-

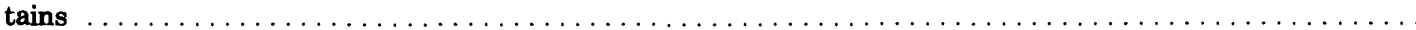

9. Contoured equal-area projections of poles to bedding $\left(S_{0}\right)$ in the Latady and Mount Poster Formations .........

10. Photograph of fine-grained sandstone and shale of the Latady Formation on west face of Mt. McKibben, McCaw Ridge area

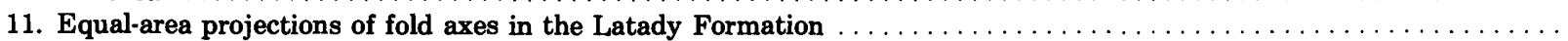

12. Photograph of steeply plunging fold in the Latady Formation at contact with a granodiorite pluton that underlies the eastern

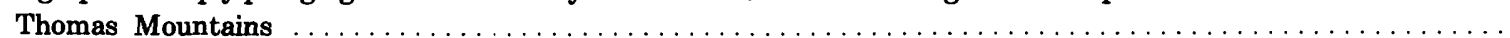

13-19. Contoured equal-area projections of:

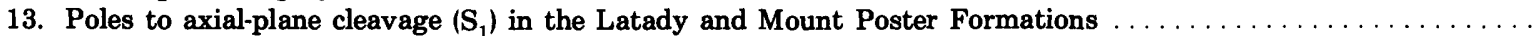

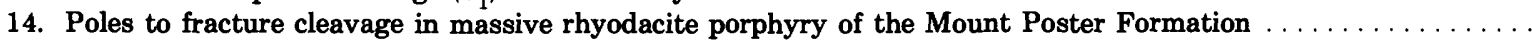

15. Poles to joint surfaces in folded layered rocks of the Latady Formation

16. Poles to joint surfaces in massive rhyodacite porphyry and layered volcanic rocks of the Mount Poster Formation

17. Poles to quartz-filled fractures in sedimentary rocks of the Latady Formation $\ldots \ldots \ldots \ldots \ldots \ldots \ldots \ldots$

18. Poles to joint surfaces in stocks

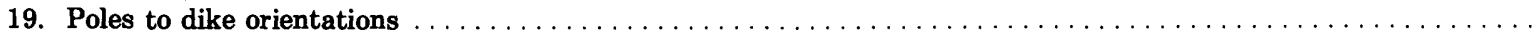

20. Rose diagram of strike directions of all observed high-angle faults cutting the Latady Formation in the Orville Coast and eastern Ellsworth Land

21. Paleomagnetic poles for 111- to 103-Ma plutons from eastern Ellsworth Land, Sweeney and Hauberg Mountains, Lassiter

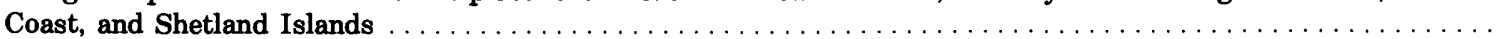

22. Demagnetization diagrams for four selected samples from the Behrendt Mountains $\ldots \ldots \ldots \ldots \ldots \ldots \ldots$

23. Schematic cross section showing major tectonic elements in Late Jurassic and middle Cretaceous time ..........

24. Diagram of hypothetical plate configuration of the Antarctic Peninsula area during the Late Cretaceous and early Tertiary 


\section{TABLES}

TABLE 1. Paleomagnetic and geochronologic data from mid-Cretaceous rocks from the Behrendt and Merrick Mountains, eastern

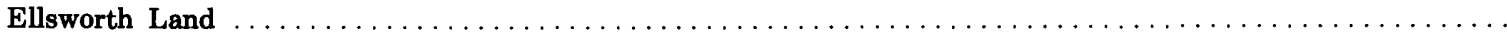

2. Paleomagnetic and geochronologic data from mid-Cretaceous rocks from the Antarctic Peninsula $\ldots \ldots \ldots \ldots \ldots \ldots$ 


\title{
STRUCTURAL GEOLOGY AND TECTONICS OF THE ORVILLE COAST REGION, SOUTHERN ANTARCTIC PENINSUla, ANTARCTICA
}

\author{
By Karl S. Kellogg and Peter D. Rowley
}

\begin{abstract}
The oldest rocks in the Orville Coast of the southern Antarctic Peninsula and in adjacent parts of eastern Ellsworth Land belong to a Middle and Late Jurassic calc-alkalic magmatic arc that developed along the axial part of the peninsula. The main exposed product of the magmatism, which developed in response to eastward subduction beneath the Pacific margin of the peninsula, is mostly andesitic to dacitic volcanic rocks of the Mount Poster Formation. These rocks interfinger southeastward with Middle and Upper Jurassic sedimentary rocks of the Latady Formation, deposited in a back-arc basin. Deposition was concurrent with early stages of opening of the Weddell Sea, during which time the Antarctic Peninsula was moving right laterally with respect to East Antarctica along the Weddell fault, a proposed transform east of the peninsula that is continuous with the Transantarctic rift system.
\end{abstract}

The Latady and Mount Poster Formations were strongly folded during Late Jurassic and (or) Early Cretaceous time during the Palmer Land deformational event. Fold axes are parallel to the prominent bend or orocline in the southern Antarctic Peninsula, and vergence is to the south or southeast. Axial-plane cleavage is well developed in finer grained rocks, as is a set of extension joints oriented perpendicular to fold axes. Thrust faults with apparently small displacement dip to the north or northwest in the Hauberg and Wilkins Mountains. These features suggest that deformation is thin skinned, similar to fold-and-thrust belts elsewhere, and was perhaps caused by gravitational spreading from the thickened magmatic arc. A collisional origin for the Palmer Land deformational event, however, cannot be discounted. For example, the deformational event may be related to the Rangitata orogeny recognized in New Zealand, which is thought to have resulted from the suturing of two tectonostratigraphic terranes, or it may have resulted from the collision of the Antarctic Peninsula magmatic arc with the Gondwana craton, which now lies to the south of the Orville Coast.

Renewed arc magmatism, resulting in emplacement of gabbroic to granitic plutons of the Lassiter Coast Intrusive Suite, began before $115 \mathrm{Ma}$, sometime after folding ceased, and continued for at least 15 m.y. Dikes of similar composition to the plutonic rocks and anastomosing, randomly oriented, hydrothermal quartz veins were intruded during late stages of plutonism; copper mineralization associated with the late hydrothermal activity took place in the Sky-Hi Nunataks and Merrick Mountains. Dikes are generally oriented parallel to the extension-joint direction in sedimentary rocks in the Orville Coast but are oblique to that direction in eastern Ellsworth Land. The dikes may be related to northwest-directed shear produced by early stages of movement along the Ellsworth fault system, an extinct transform fault

Manuscript approved for publication October 28, 1988. that is thought to have formed a major crustal discontinuity between the peninsula and ice-covered regions to the southwest.

Small-displacement, predominantly right-lateral strike-slip faults, oriented about $\mathrm{N} .70^{\circ} \mathrm{W}$., are probably satellitic to the right-lateral Ellsworth fault system. Drag along the Ellsworth fault system may account for clockwise-rotated paleomagnetic directions from Lower Cretaceous intrusive rocks in the Sweeney and Hauberg Mountains of the Orville Coast; the directions are rotated about $50^{\circ}$ compared to those from similar-age rocks elsewhere on the Antarctic Peninsula. The Ellsworth fault system may be a continuation of the Tharp fracture zone in the southeast Pacific Ocean, which was active between about 85 and $50 \mathrm{Ma}$. The southern peninsula underwent deep erosion and peneplanation in the Late Cretaceous and early Tertiary, followed by gradual arching and rifting. Continuation of extension into the late Tertiary is suggested by occurrences of alkalic basalt of apparent late Miocene and Pliocene age.

\section{INTRODUCTION}

The Orville Coast is a region of isolated mountain ranges and nunataks along the southeastern coast of Palmer Land, Antarctic Peninsula, adjacent to the Ronne Ice Shelf (fig. 1). The rocks of the Orville Coast region define the southernmost limit in the Antarctic Peninsula of a Mesozoic and Cenozoic orogenic belt that is continuous with the Andean orogenic belt of South America. The orogenic belt is characterized by widespread volcanism, calc-alkalic plutonism, and deformation. This igneous and tectonic belt bends west through the Orville Coast and eastern Ellsworth Land and continues along the Pacific coast of Ellsworth Land (Rowley and others, 1985, in press) and Marie Byrd Land (LeMasurier and Wade, 1976). Plate tectonic reconstructions indicate that New Zealand forms part of a small continental-crustal plate (Weissel and others, 1977) that was attached to Marie Byrd Land prior to $80 \mathrm{Ma}$. Therefore many Mesozoic structures of New Zealand may have been part of the same orogenic belt recognized in the Antarctic Peninsula (Cooper and others, 1982).

The change in trend of the orogenic belt around the geographic bend of the southern Antarctic Peninsula is referred to as an orocline in this report. The original 


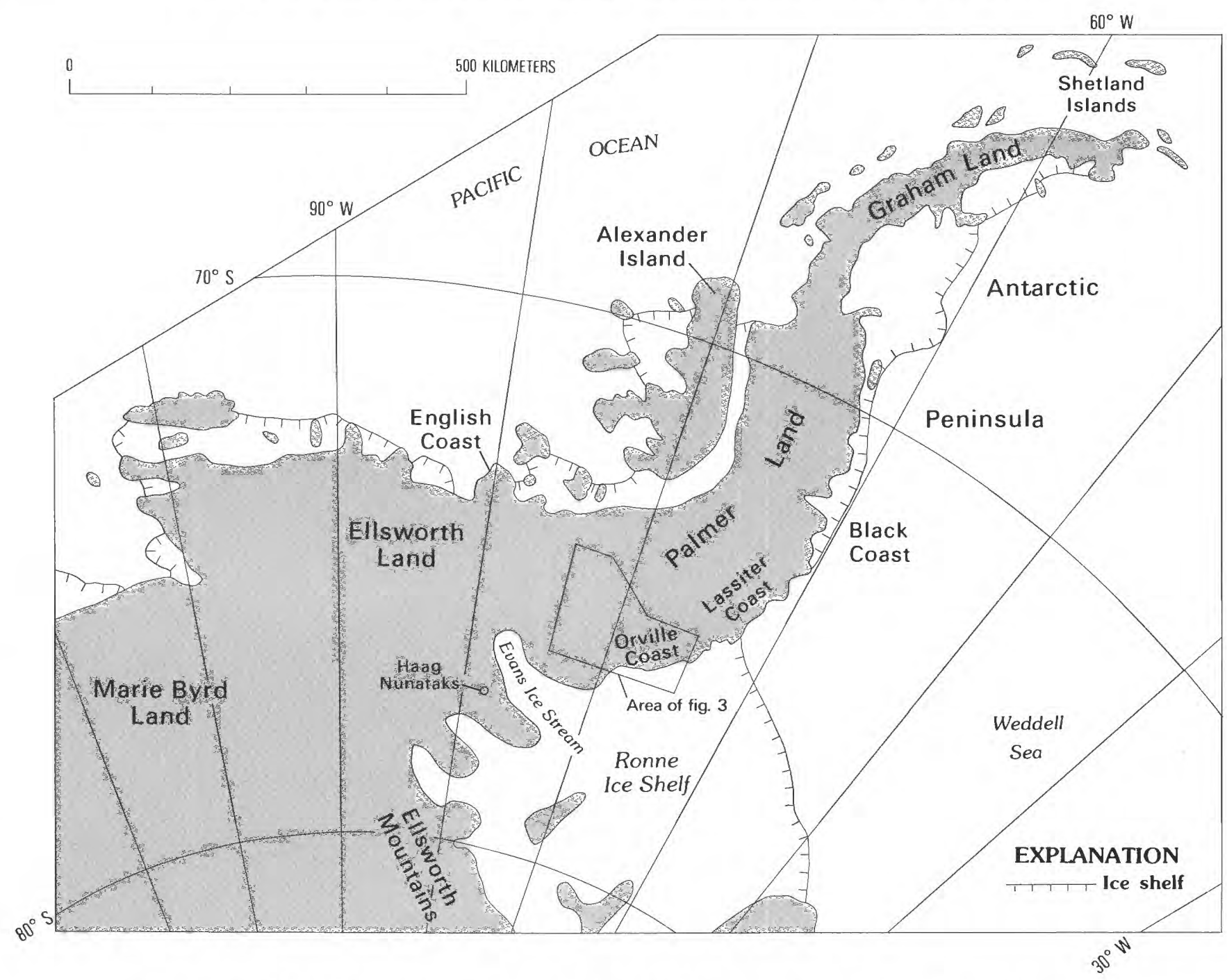

FIGURE 1.-Index map of part of West Antarctica showing major geographic features discussed in text.

definition of orocline incorporated the idea that such curvature is due to horizontal bending of the crust or "deformation in plan" (Carey, 1958). No such genetic interpretation is implied by our use of the term orocline, although, as we shall discuss, deformation in plan locally may have occurred.

Most rocks and geologic structures of the southern Antarctic Peninsula reflect subduction beneath the west side of the peninsula during Mesozoic and perhaps late Paleozoic time (Weissel and others, 1977; Barker, 1982; Storey and Garrett, 1985). An axial, calc-alkalic magmatic-arc sequence, as old as Early Jurassic (Thomson, 1982; Rowley and others, 1983), and a Middle and Upper Jurassic sedimentary back-arc basin sequence (Suárez, 1976; Laudon and others, 1983; Thomson, 1983) are well represented in the area. On the Pacific side of the peninsula, a late Mesozoic accretionary wedge
(LeMay Group; Tranter, 1986, in press) and fore-arc basin (Fossil Bluff Formation; Taylor and others, 1979) are well exposed on Alexander Island. Whereas subduction-related features in Palmer Land are almost entirely of Mesozoic age, similar features in Graham Land are as young as Tertiary (Thomson and Pankhurst, 1983). This northward younging of magmatic events is related to an incremental northward cessation of subduction as transform-bounded segments of the Aluk-West Antarctic plate intersected the trench along the west side of the peninsula (Barker, 1982). Subduction ceased beneath the southern peninsula about $50 \mathrm{Ma}$ (Barker, 1982); however, subduction is still occurring adjacent to and north of the Shetland Islands (Weissel and others, 1977).

The Antarctic Peninsula is one of several crustal blocks that have been proposed to make up West 
Antarctica (Dalziel and Elliot, 1982; Dalziel and others, 1987) (fig. 2), although the blocks probably are separated by small extensional basins along which there has been a minimum of transcurrent movement (Storey, in press). Orville Coast and eastern Ellsworth Land are centrally located within the proposed cluster of crustal blocks, which underlines the importance of understanding the geology of this region.

The geology of eastern Ellsworth Land was discussed by Laudon and others (1970) and Laudon (1972). Rowley (1978) and Rowley and others (1983) summarized the geologic history of the Orville Coast and eastern Ellsworth Land, including a general discussion of some structural features. Stanek (1987) reported observations made on the geology of the eastern Orville Coast. Thomson and others (1978) and Laudon and others (1983) discussed the sedimentary rocks of the Latady Formation, and Thomson (1983) described fossils from the Latady Formation. The bearing of paleomagnetic data from Cretaceous intrusive rocks on possible oroclinal bending of the southern peninsula has been given by Kellogg (1980).

\section{ACKNOWLEDGMENTS}

We are grateful to all members of the Orville Coast expedition (1979-1980), J.M. Boyles, P.E. Carrara, T.S. Laudon, M.R.A. Thomson, and W.R. Vennum, all of whom collected structural data. The input of A.B. Ford, Warren Hamilton, R.L. Reynolds, and D.L. Schmidt during numerous and stimulating discussions greatly improved this report, as did thorough reviews by A.B. Ford and D.J. Lidke.

\section{GEOLOGIC SETTING}

The geology of the Orville Coast and vicinity is shown on figure 3 and the geologic and tectonic events of the region are summarized on figure 4; a discussion of many of the regional tectonic features shown on figure 4 are found in later sections of the report.

The oldest known rocks in the Orville Coast belong to locally fossiliferous, fine- to medium-grained, largely volcanogenic siltstone and shale and subordinate sandstone of the Latady Formation, first described from its type locality in the southern Lassiter Coast by Williams and others (1972). In northerly exposures, especially in the Sweeney Mountains, interbedded, mostly dacitic lava flows and ash-flow tuffs are included in the Latady Formation where sedimentary rocks predominate. Similar and probably correlative sedimentary rocks in northern and central Palmer Land are

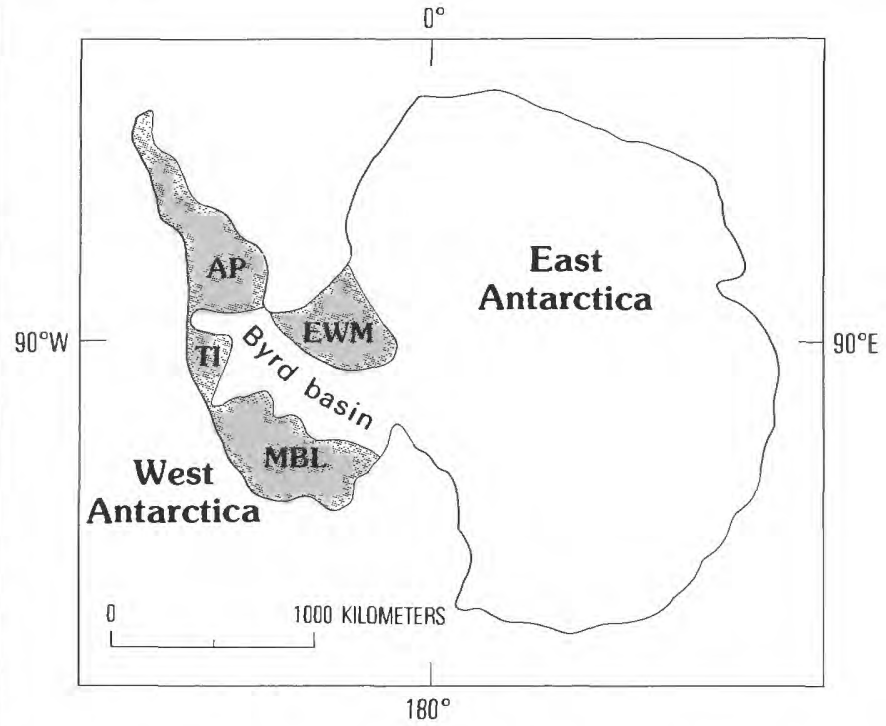

FIGURE 2.-Sketch map of Antarctica showing continental crustal blocks (shaded) of West Antarctica, as proposed by Dalziel and others (1987). AP, Antarctic Peninsula crustal block; TI, Thurston Island-Eights Coast crustal block; MBL, Marie Byrd Land crustal block; EWM, Ellsworth and Whitmore Mountains crustal block.

called the Mount Hill Formation (Singleton, 1980). The Latady Formation is Middle and Late Jurassic in the Behrendt Mountains (fig. 3) but is known only to be Late Jurassic elsewhere (Thomson, 1983).

The Latady Formation is at least several thousand meters thick; neither the top nor bottom has been observed. Depositional facies vary from north to south from lagoonal, fluvial, and lacustrine near the volcanic arc in the Sweeney Mountains, to marine deltaic in the Hauberg and Wilkins Mountains, and to marine shelf at Cape Zumberge (Thomson and others, 1978; Laudon and others, 1983; Thomson, 1983).

Toward the axis of the Antarctic Peninsula, rocks of the Latady Formation interfinger with and grade into calc-alkalic basaltic to rhyolitic lava flows, ash-flow tuff, and subordinate volcaniclastic sedimentary rocks correlated with the Mount Poster Formation of the Lassiter Coast (Rowley and others, 1982); the Mount Poster Formation is considered part of the Antarctic Peninsula Volcanic Group of Thomson (1982). These interbedded sedimentary and volcanic rocks, best exposed in the Sweeney Mountains, are interpreted as the interfingering contact between sedimentary rocks of a mostly marine back-arc basin (Suárez, 1976) in the southeast (Latady Formation) and volcanic rocks of the Mount Poster Formation deposited subaerially in the northwest (Rowley and others, 1983). The Mount Poster Formation has not been directly dated, but the inferred interfingering relationship with the Latady Formation suggests a Middle to Late Jurassic age. 


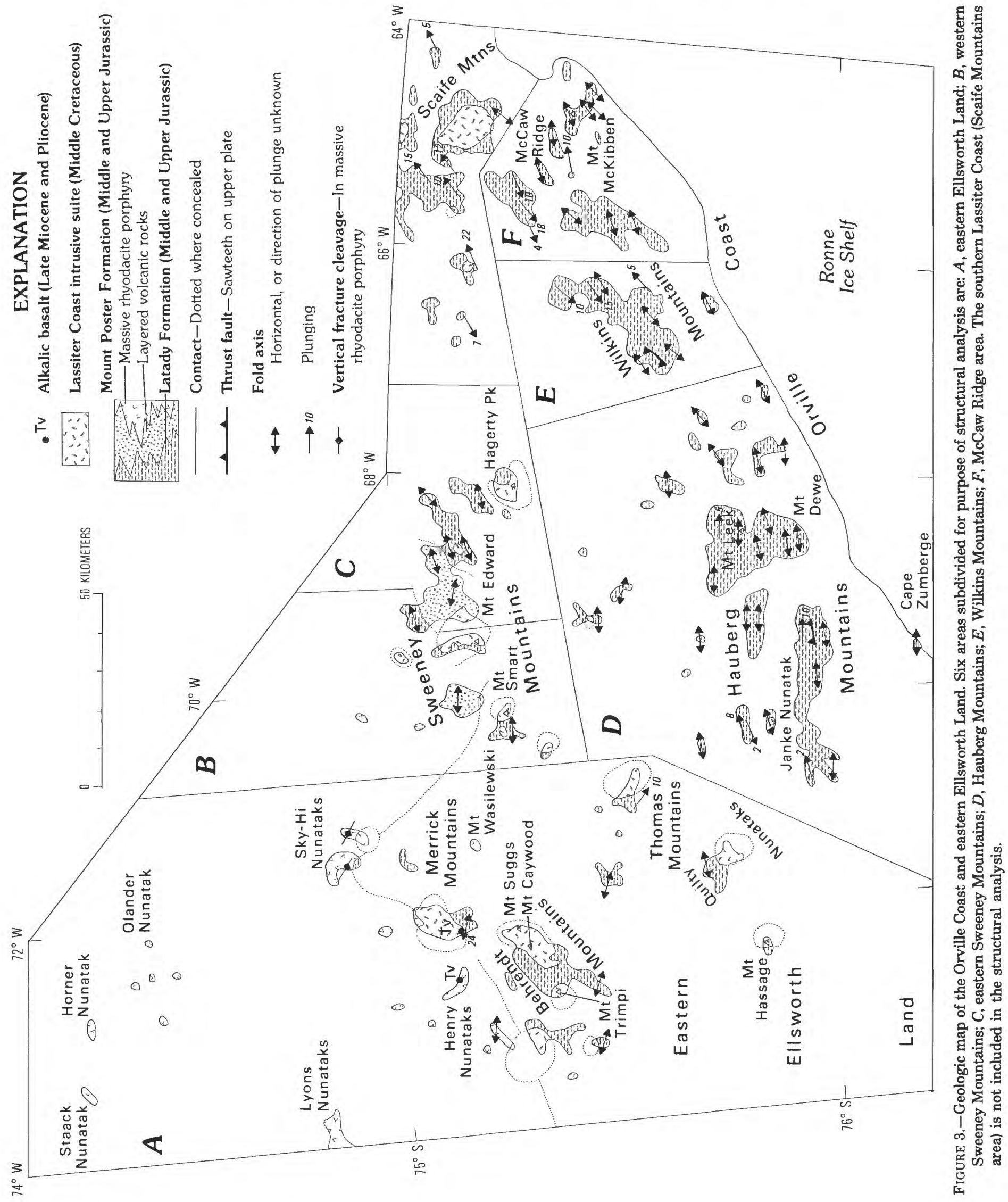




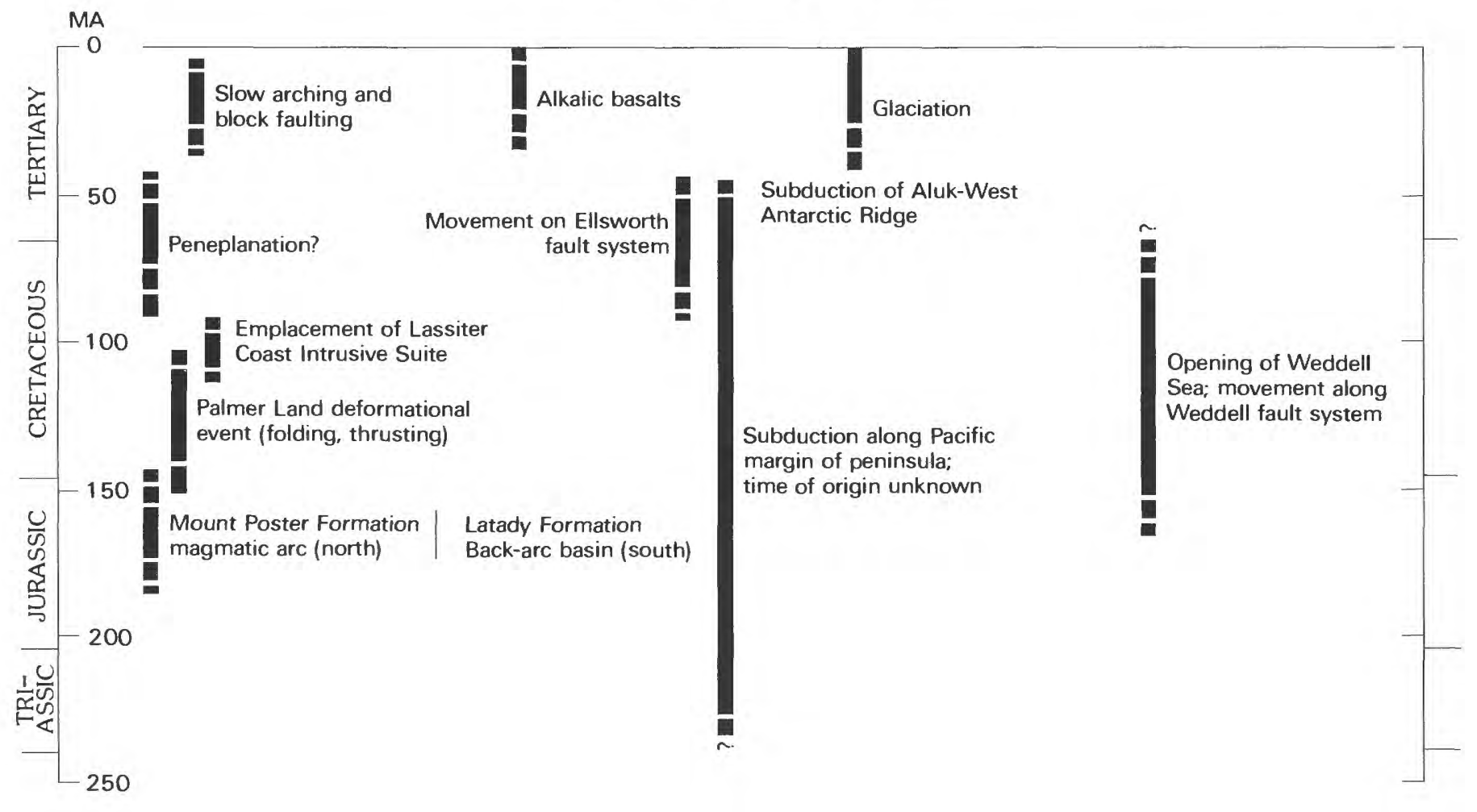

Figure 4.-Geologic and tectonic events for the Orville Coast region. Dashed line represents uncertain placement and query indicates that event may extend in age for unknown time.

Massive rhyodacite porphyry occupies much of the northern, inland portions of the area westward from the northern Sweeney Mountains; similar rocks have been mapped as far west as the English Coast (Rowley and others, in press). Although no contact has been observed between this massive unit and either the Latady Formation or the layered volcanic rocks of the Mount Poster Formation, it is correlated with the Mount Poster Formation. Rocks of the Mount Poster Formation mapped in eastern Ellsworth Land (area $A$ of fig. 3) are composed largely of unstratified rhyodacite, and except in the area of Olander and Horner Nunataks, the rock is porphyritic and contains partially resorbed beta quartz and plagioclase phenocrysts as large as $1 \mathrm{~cm}$ across. This unit probably represents thick lava flows, ash-flow tuff, and volcanic domes (Rowley and others, 1983), or a strongly welded intracaldera tuff.

After deposition of the Mount Poster and Latady Formations, the layered rocks were strongly folded about axes that are parallel to the arcuate trend of the southern peninsula (fig. 3); the extent of folding in the unstratified rhyodacite is unknown. This period of Late Jurassic and (or) Early Cretaceous folding was named the Palmer Land deformational event by Kellogg and Rowley (in press). Folds and local thrusts of this event, including those in the Lassiter Coast and the English
Coast of eastern Ellsworth Land, have been described by Williams and others (1972), Kellogg and Rowley (1974), Kellogg (1979), Rowley and Williams (1982), and Rowley and others (1983, in press).

Following the Palmer Land deformational event, folded Jurassic rocks were intruded by calc-alkalic gabbroic to granitic stocks and batholiths and magmatic, finegrained dikes of similar composition, all of the middle Cretaceous Lassiter Coast Intrusive Suite (Vennum and Rowley, 1986). With the exception of a 122-Ma K-Ar (potassium-argon) age on hornblende from the Sky-Hi Nunataks, rocks of the intrusive suite have been dated within the study area by $\mathrm{K}-\mathrm{Ar}$ or $\mathrm{Rb}-\mathrm{Sr}$ (rubidiumstrontium) methods as about 113-100 Ma (Halpern, 1967; Mehnert and others, 1975; Farrar and others, 1982; Rowley and others, 1988; Pankhurst and Rowley, in press). Systematic geographic trends in the ages are not apparent in the southern peninsula, although mafic phases are generally older (Pankhurst and Rowley, in press).

The area of exposed rock of the Lassiter Coast Intrusive Suite is significantly less in the Orville Coast than farther northeast on the Lassiter Coast (Vennum and Rowley, 1986); this probably reflects more restricted plutonism and (or) less uplift southwestward along the axis of the arc. 
Other than upper Tertiary and Quaternary glacial deposits, the only Cenozoic material in the region is olivine-phyric basaltic lava flows in the Merrick Mountains (Laudon and others, 1970; Vennum and Laudon, 1988) and at Henry Nunataks. Halpern (1971) reported a $\mathrm{K}-\mathrm{Ar}$ age of $6 \mathrm{Ma}$ for the basaltic rocks of the Merrick Mountains.

\section{STRUCTURAL GEOLOGY}

We have divided the region into six areas (fig. 3) in order to show the changes in different structural elements through the oroclinal bend in the Orville Coast and eastern Ellsworth Land: $A$, eastern Ellsworth Land; $B$, western Sweeney Mountains; $C$, eastern Sweeney Mountains; $D$, Hauberg Mountains; $E$, Wilkins Mountains; $F$, McCaw Ridge area.

\section{STRUCTURES OF THE LATADY AND MOUNT POSTER FORMATIONS}

\section{FOLDS}

The Latady Formation and at least the layered volcanic rocks of the Mount Poster Formation were everywhere folded during the Late Jurassic and (or) Early Cretaceous Palmer Land deformational event (Kellogg and Rowley, in press). Folds are open to isoclinal, and wavelengths of folds range generally from several tens of meters to a kilometer or more (figs. 5-8). Chevron geometry is common (figs. 6 and 8 and front cover). Fold axes are horizontal to gently plunging and are oriented parallel to the general trend of the coastline (fig. 3). Thus, the structural fabric defines an orocline, striking about $\mathrm{N} .50^{\circ} \mathrm{E}$. in the northeastern Orville Coast, eastwest in the central Hauberg Mountains, and N. $75^{\circ} \mathrm{W}$. in eastern Ellsworth Land. Figure 9 shows contoured equal-area projections of poles to bedding $\left(\mathrm{S}_{0}\right)$ for the six

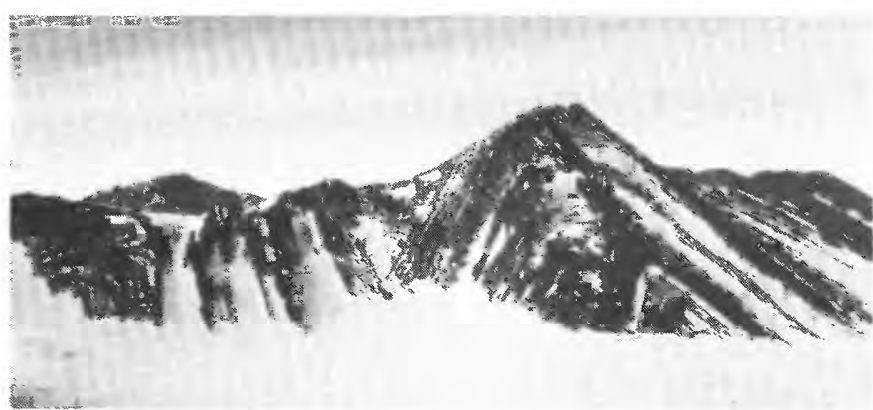

FIGURE 5.-View to the east of prominent anticline and syncline in the Latady Formation on west face of Mt. Dewe, eastern Hauberg Mountains. Fold axes are nearly horizontal. Distance along ridge is about $2 \mathrm{~km}$.

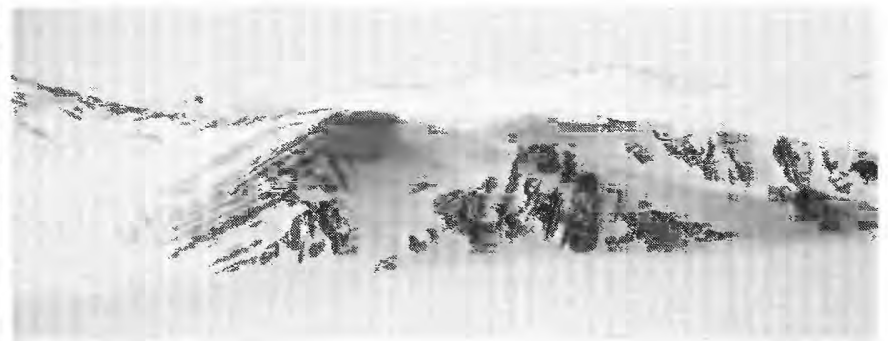

Figure 6.-View to the east of chevron folds in the Latady Formation along a small ridge $28 \mathrm{~km}$ due east of Janke Nunatak, northwestern Hauberg Mountains. Prominent vergence is to the south. Distance along ridge is about $2 \mathrm{~km}$. A flat fault, with no more than about $20 \mathrm{~m}$ displacement, offsets axial plane of prominent anticline in left side of photograph.

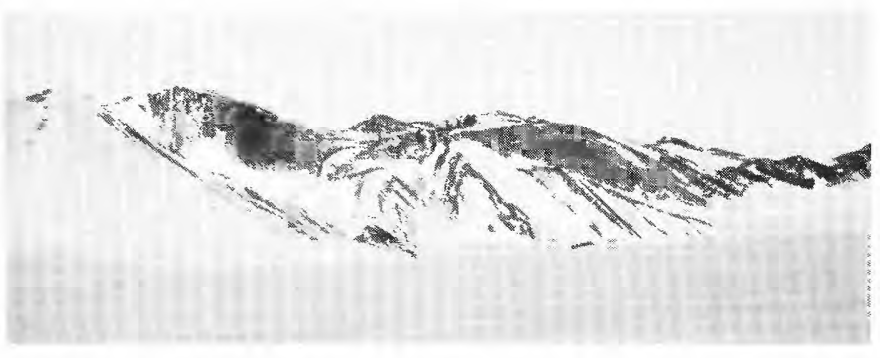

FIGURE 7.-View to the east of tight folds in the Latady Formation on northern part of ridge that contains Mt. Dewe (fig. 5), eastern Hauberg Mountains. Vergence is to the south, although this is not apparent in the photograph. Distance along ridge is about $4 \mathrm{~km}$.

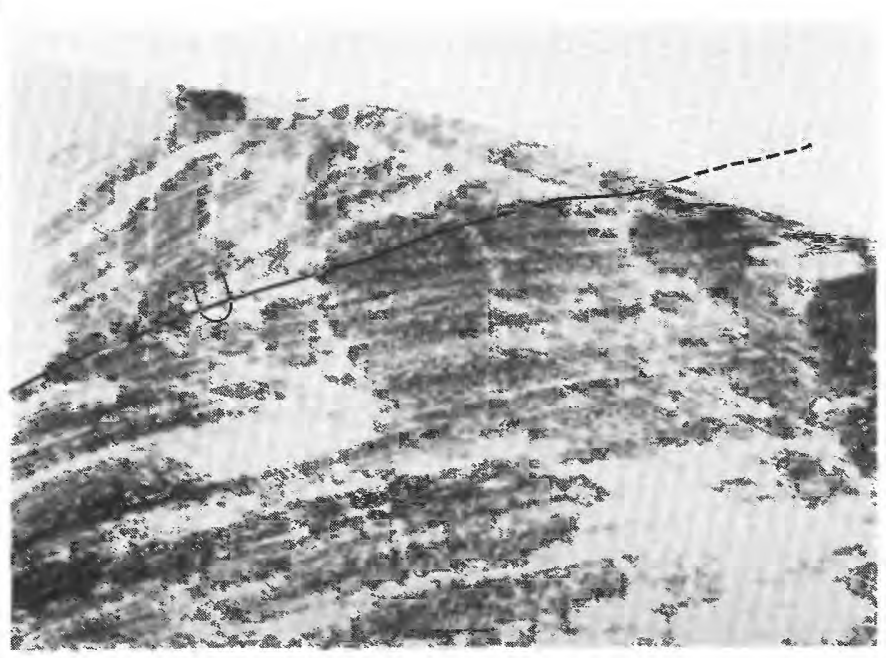

FIGURE 8.-View to the northeast of tight recumbent syncline cut by high-angle apparent normal faults in the Latady Formation on flank of Mt. Leek, northeastern Hauberg Mountains. Distance along skyline is approximately $0.5 \mathrm{~km}$. 
areas of the Orville Coast and eastern Ellsworth Land. Note that the change in strike of fold axes is not continuously more northerly toward the northeast; in the McCaw Ridge area (fig. $9 F$ ) fold axes are more easterly than in the Wilkins Mountains (fig. $9 E$ ) to the southwest.

Many of the folds are asymmetric (figs. 6, 7, and 10) and some have overturned limbs (figs. 8 and 10). Axial planes generally dip steeply to the north and northwest, indicating compression perpendicular to the peninsula and vergence toward the south and southwest. Asymmetric folding is not ubiquitous however; throughout most of the Hauberg Mountains the folds are nearly symmetric (figs. 5 and $9 D$ ), although southern vergence is locally common (figs. 6 and 7 and front cover).

Fold axes were determined from pi diagrams, in which the best great circle through a set of poles to bedding is determined, and from bedding-cleavage $\left(\mathrm{S}_{0}-\mathrm{S}_{1}\right)$ intersections. Mean directions determined by both methods are similar (fig. 11); mean fold axes are horizontal or nearly horizontal in all areas.

Local, disharmonic folds in the Latady Formation associated with forceful intrusion of Cretaceous plutons are rare in the Orville Coast, implying that most plutons were passively emplaced. Steeply plunging small folds were locally observed, however, in the Thomas Mountains of eastern Ellsworth Land (fig. 12). In contrast to the apparent scarcity of evidence for forceful intrusion in the Orville Coast region, disharmonic folding adjacent to plutons is common in the northern Lassiter Coast (Kellogg and Rowley, 1974). This may simply reflect a comparatively deeper level of erosion in the northern Lassiter Coast, such that effects of higher temperature, more-ductile deformation are exposed.

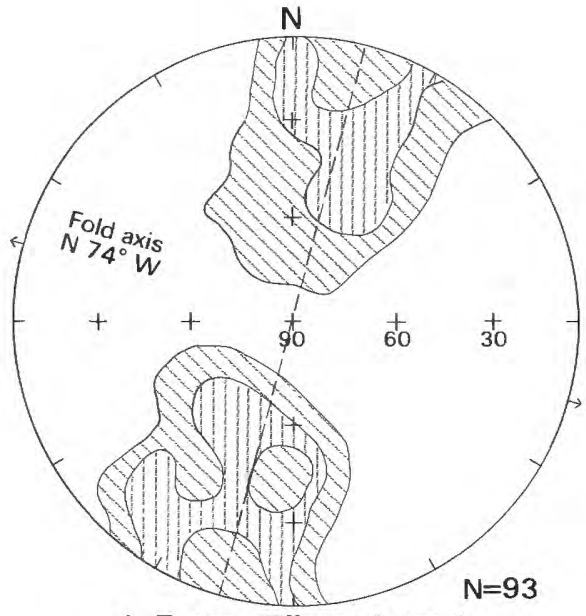

A, Eastern Ellsworth Land

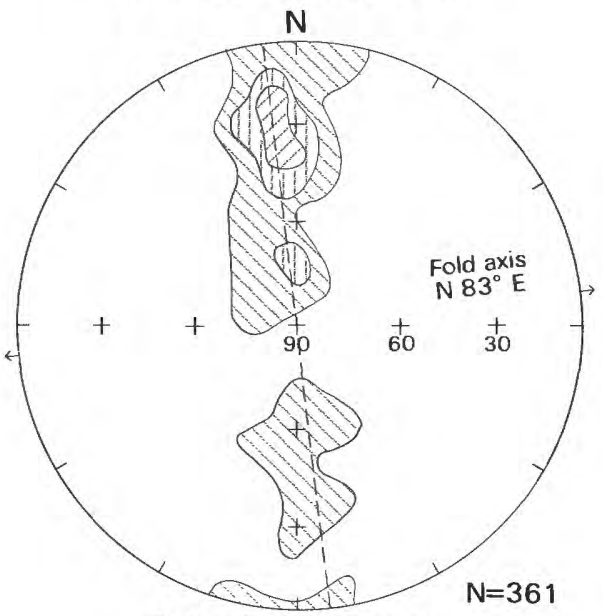

D. Hauberg Mountains

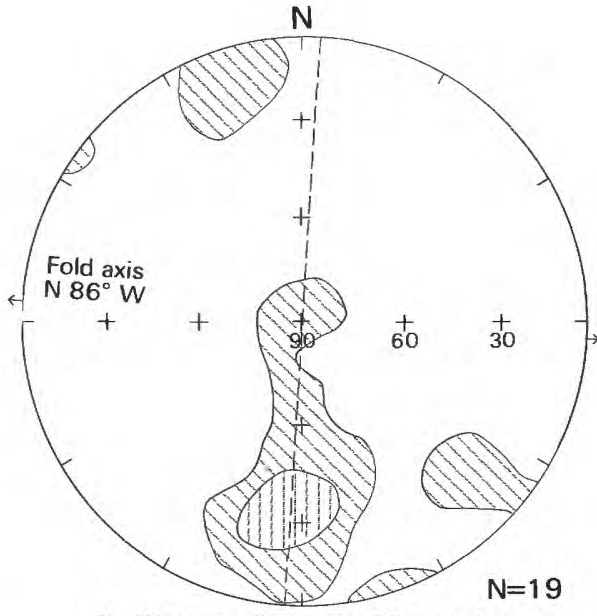

$B$, Western Sweeney Mountains

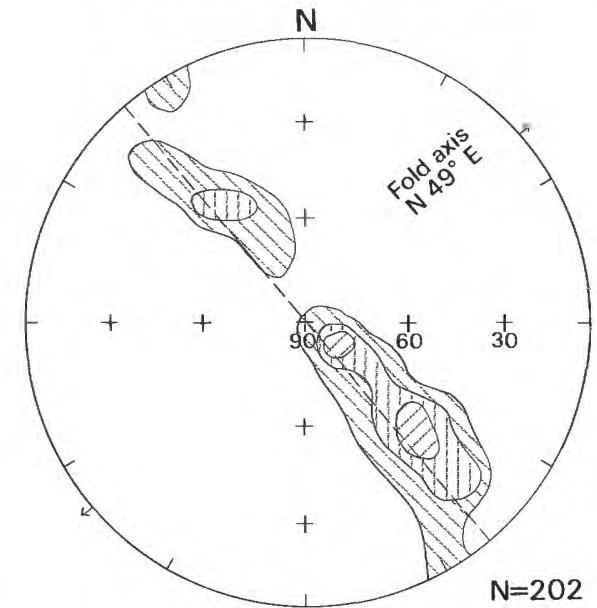

E, Wilkins Mountains

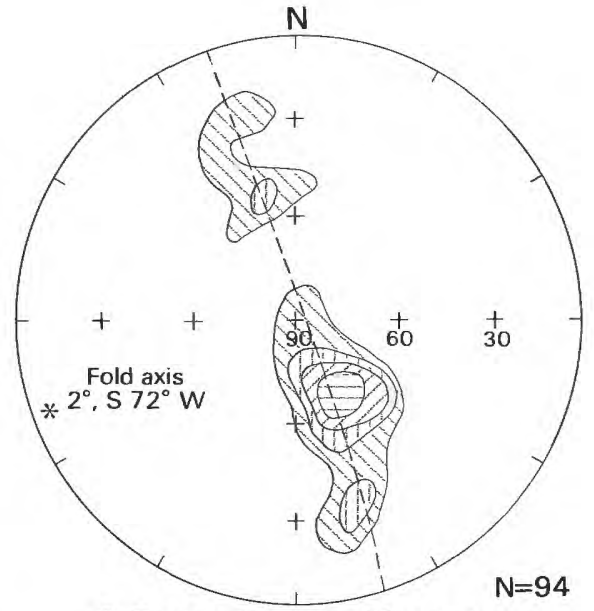

$C$, Eastern Sweeney Mountains

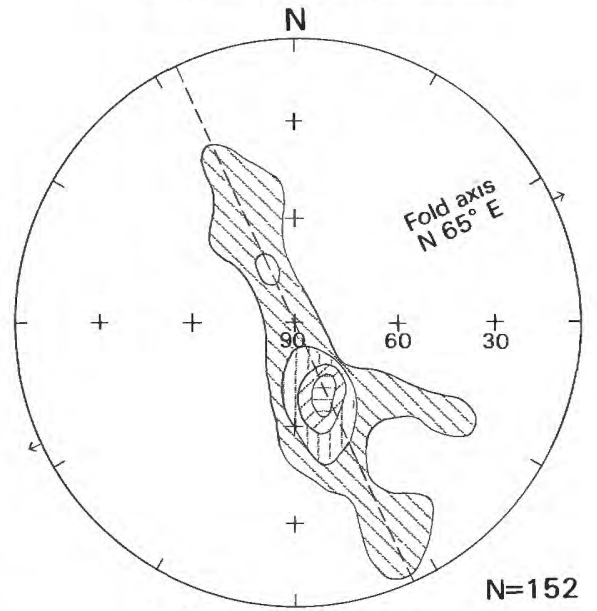

F, McCaw Ridge area

Figure 9.-Contoured equal-area projections of poles to bedding $\left(\mathrm{S}_{0}\right)$ in the Latady and Mount Poster Formations for the six areas shown on figure 3. Successive contours are at 2, 4, 6, and 8 percent of poles per 1 percent area. $N$ is number of observations. Dashed lines are estimated best mean girdle for folds in each area. Mean fold axis, normal to this girdle, is also indicated. 


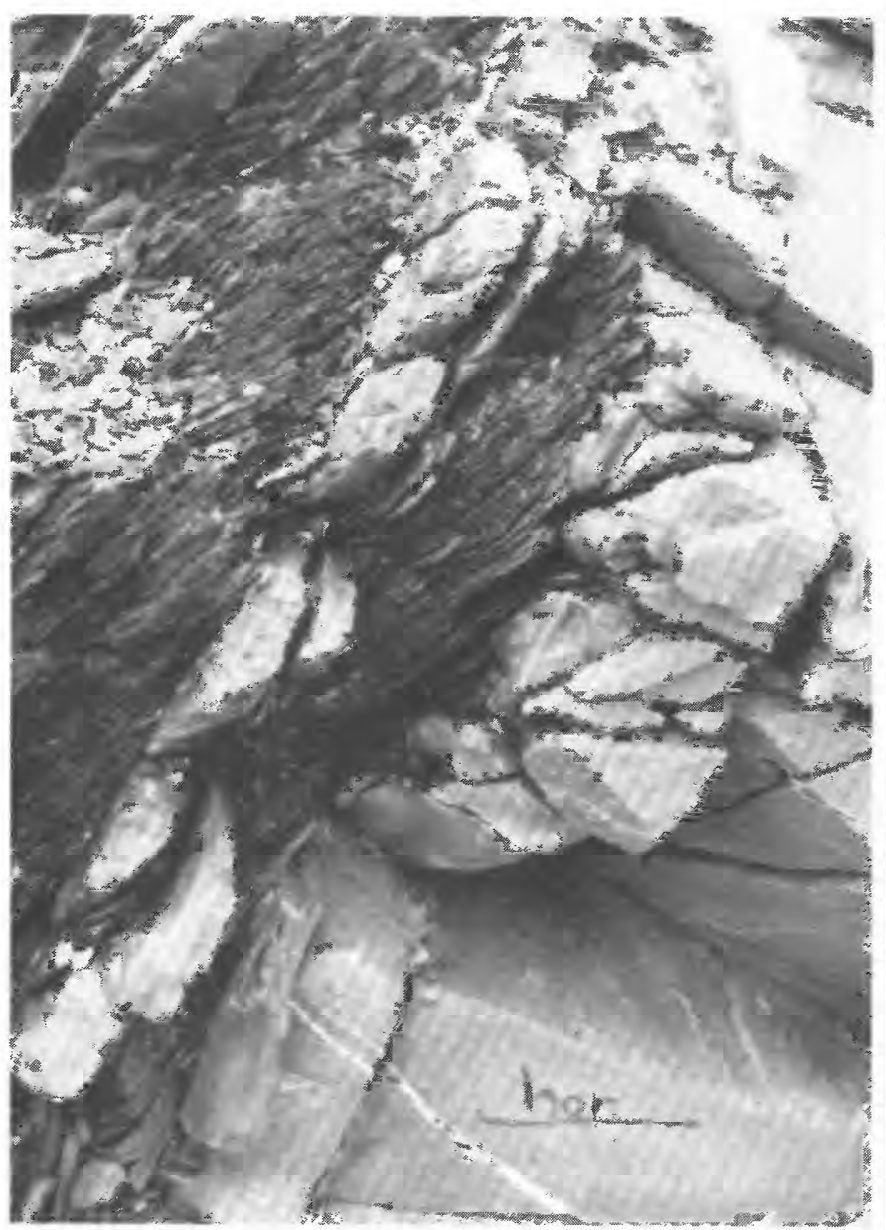

FIGURE 10.- View to the northeast of outcrop of fine-grained sandstone (massive, light-colored rock) and shale (cleaved, dark-colored rock) of the Latady Formation on west face of Mt. McKibben, McCaw Ridge area. Rocks are overturned, on southeast limb of a recumbent anticline; axial-plane cleavage $\left(\mathrm{S}_{1}\right)$ dips more gently than does bedding $\left(\mathrm{S}_{0}\right)$. A quartz-filled fracture, as wide as $1 \mathrm{~cm}$, is in lower part of photograph. "hor" shows horizontal line marked on outcrop. Width of outcrop at bottom of photograph is about $1 \mathrm{~m}$.

AXIAL-PLANE CLEAVAGE

Well-developed, penetrative, axial-plane cleavage $\left(S_{1}\right)$ is ubiquitous in the finer grained sedimentary rocks and most layered volcanic rocks of the Latady and Mount Poster Formations (fig. 13). Axial-plane cleavage is more poorly developed in the less abundant, coarser grained rocks of the Latady Formation. The strike of $S_{1}$ directions is generally parallel to the axis of the orocline, and the dip of $S_{1}$ directions reflects the fold symmetry. Dips toward the northwest in the Wilkins Mountains and McCaw Ridge areas (figs. 10 and $13 E-F$ ) contrast with the more nearly vertical axial planes in much of the Hauberg and Sweeney Mountains (figs. 13B-D), although north- to northwest-dipping axial planes are common in the Hauberg Mountains as well.

A nonpenetrative fracture cleavage, spaced typically 1-10 cm apart, occurs in the massive rhyodacite porphyry of the Sweeney Mountains (fig. 14) and is parallel to the $S_{1}$ direction observed in nearby sedimentary and volcanic rocks. However, fracture cleavage was not observed in the massive rhyodacite porphyry of eastern Ellsworth Land (fig. 3).

\section{THRUST FAULTS}

Although spectacular folds are a prominent feature in the southern Antarctic Peninsula, thrust faults apparently are not common. A general lack of both regional marker beds and continuous, accessible exposures make the recognition of thrusts difficult and preclude the estimation of displacements. Nonetheless, thrusts with apparently small offsets, dipping about $20^{\circ}-40^{\circ} \mathrm{N}$., were observed and mapped in the Hauberg and Wilkins Mountains (fig. 3). Repetition of fossil assemblages in the southern Behrendt Mountains also suggests either that thrusts exist there (Laudon and others, 1970) or that fossils have been reworked. Stanek (1987) reported that thrusts observed in the eastern Orville Coast and southern Lassiter Coast may be Tertiary in age, although we found no evidence that suggests that thrusting is younger than Early Cretaceous.

\section{JOINTS}

Joints in folded, layered rocks of the Latady Formation (fig. 15) are predominantly vertical and are perpendicular to both fold axes (fig. 11) and cleavage directions (fig. 13) in folded layered rocks. No other consistent joint direction occurs in either sedimentary or layered volcanic rocks. The joints formed perpendicular to the minimum principal stress direction $\left(\sigma_{3}\right)$ and probably formed during a period of extension in the $\sigma_{3}$ direction. In many places, infillings of drusy quartz crystals, epidote, iron oxides, and (or) chlorite reflect that the joints were open for some period after formation. Hydrothermal fluids from devolitizing Early Cretaceous plutons are probably responsible for much of the mineralization along joint surfaces.

Joints in both the layered and massive volcanic rocks of the Mount Poster Formation show much poorer development of preferred orientation (fig. 16) than for joints in the Latady Formation (fig. 15). Alignment is best developed in the eastern Sweeney Mountains (fig. $16 \mathrm{C}$ ), where joints strike roughly parallel to the extension-joint direction in nearby layered sedimentary 


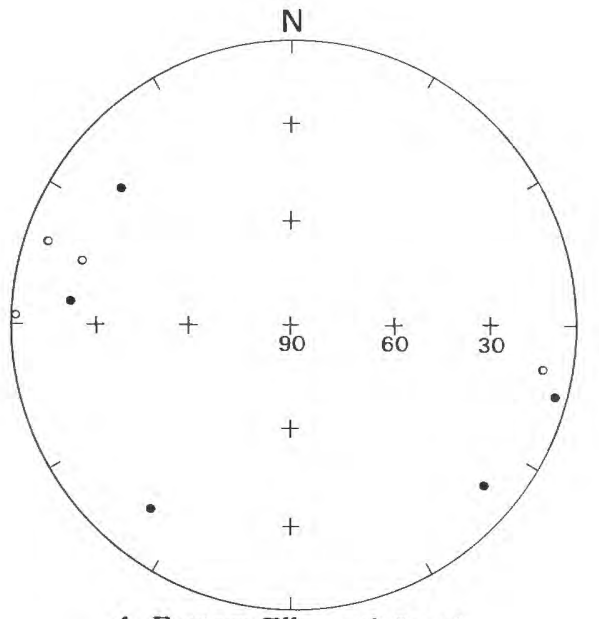

A, Eastern Ellsworth Land

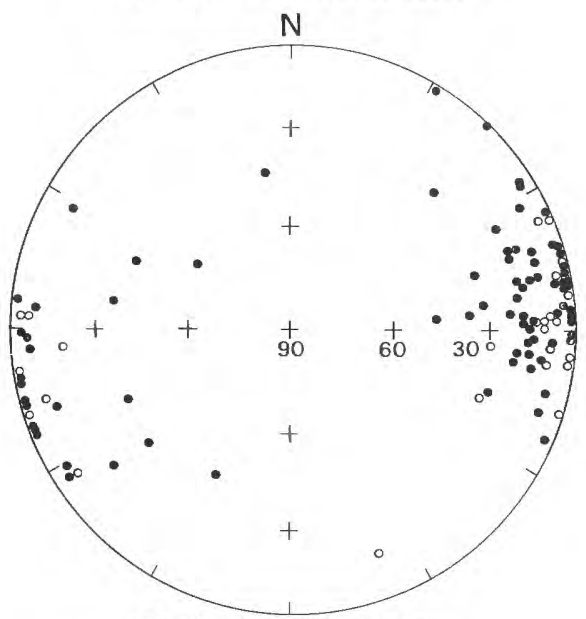

$D$, Hauberg Mountains

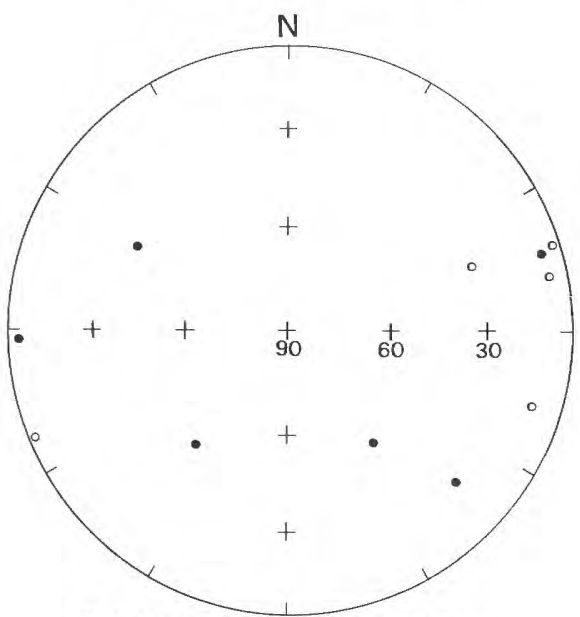

$B$, Western Sweeney Mountains

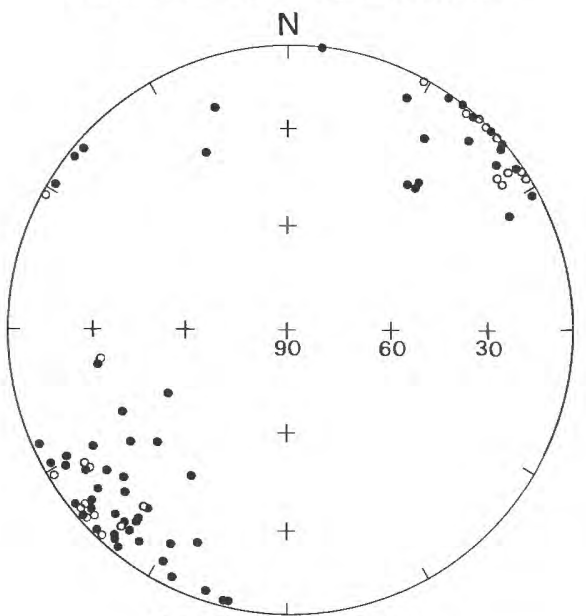

E, Wilkins Mountains

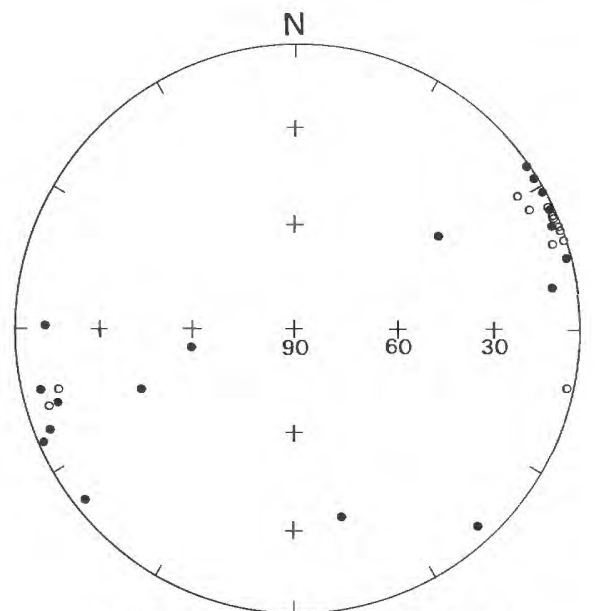

$C$, Eastern Sweeney Mountains

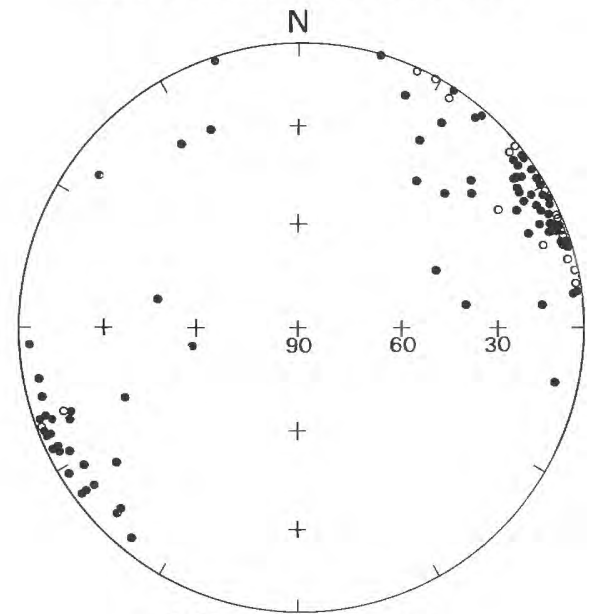

F, McCaw Ridge area

FIgURE 11.-Equal-area projections of fold axes in the Latady Formation for the six areas shown on figure 3. Solid circles represent fold axes calculated from bedding-cleavage $\left(\mathrm{S}_{0}-\mathrm{S}_{1}\right)$ intersections; open circles are mean fold axes calculated from pi analysis across individual folds.

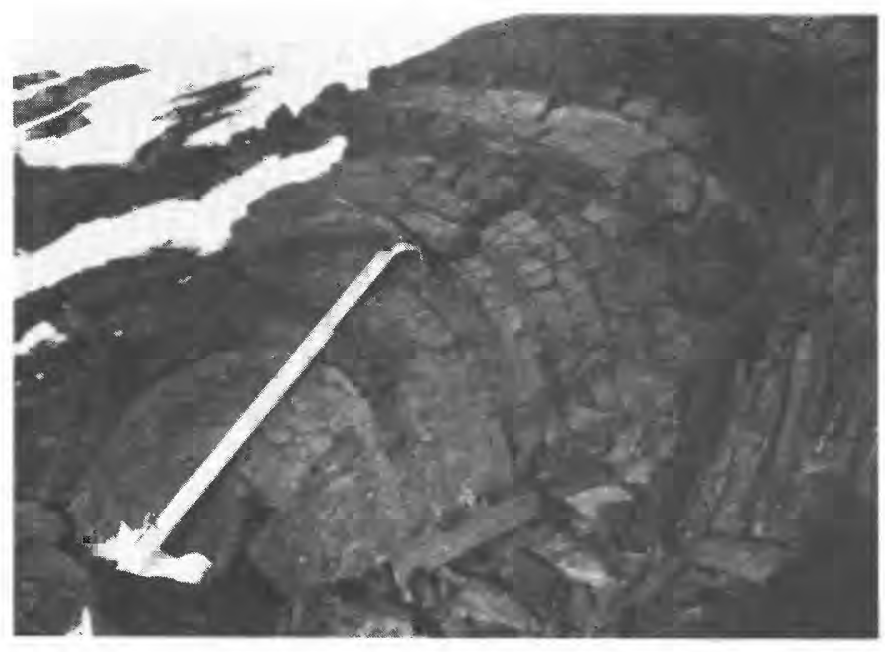

FIGURE 12.-Steeply plunging fold in the Latady Formation at contact with a granodiorite pluton that underlies the eastern Thomas Mountains (Laudon and others, 1970). Photograph by T.S. Laudon. rocks. Except for a slight tendency toward vertical orientations, the joint directions in volcanic rocks from eastern Ellsworth Land (fig. 16A) and the western Sweeney Mountains (fig. 16B) appear nearly random.

\section{QUARTZ-FILLED FRACTURES IN SEDIMENTARY ROCKS}

Quartz-filled fractures, as wide as several centimeters, cut sedimentary rocks of the Latady Formation in anastomosing patterns; quartz-filled fractures were also locally observed cutting volcanic rocks of the Mount Poster Formation but are not known in plutonic rocks. Quartz-filled fractures in sedimentary rocks make up more than 50 percent of some outcrops, although such zones are generally less than $10 \mathrm{~m}$ across. The orientation of individual fractures is nearly random (fig. 17); it has a slight tendency towards being parallel to the predominant joint direction in the sedimentary rocks 


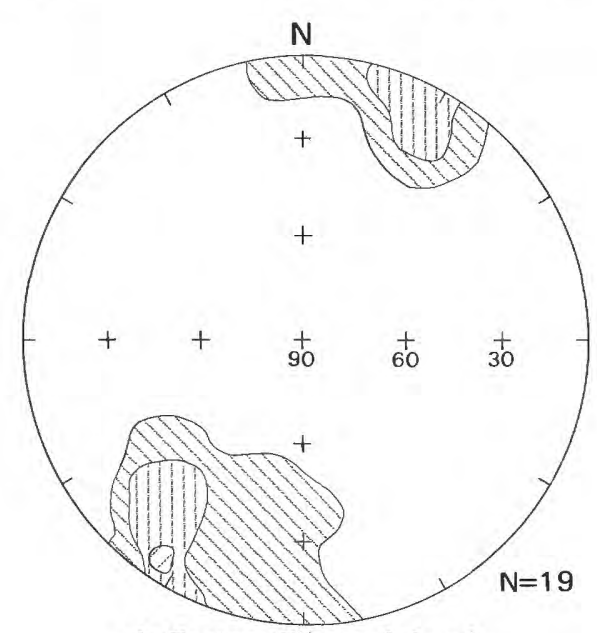

A, Eastern Ellsworth Land

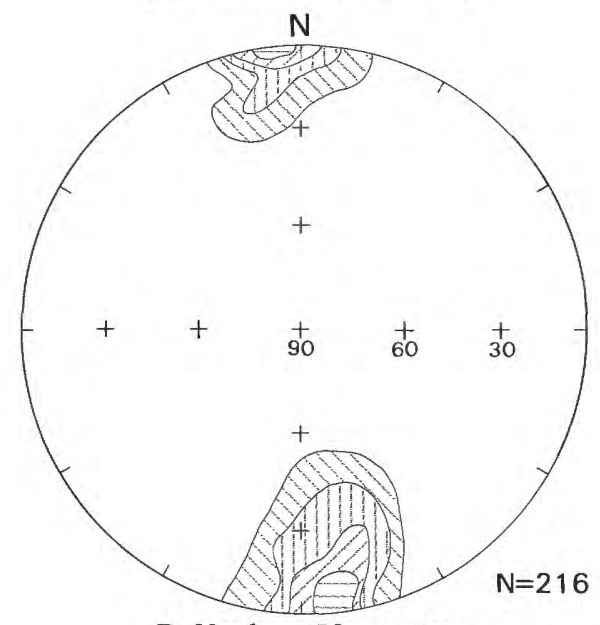

$D$, Hauberg Mountains

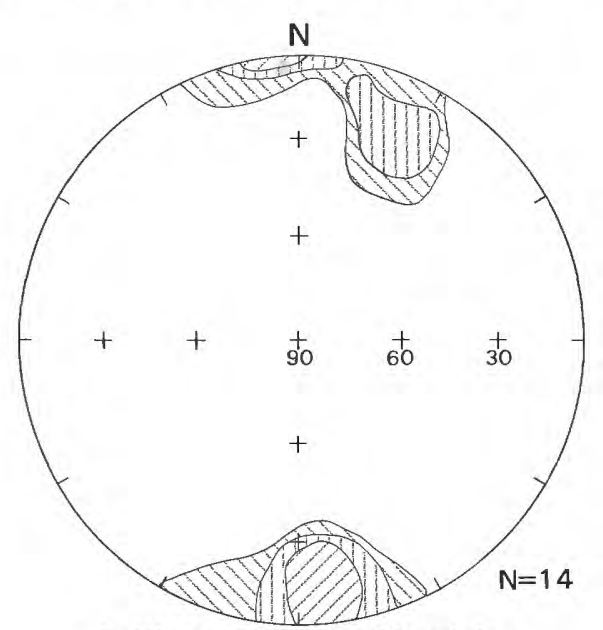

$B$, Western Sweeney Mountains

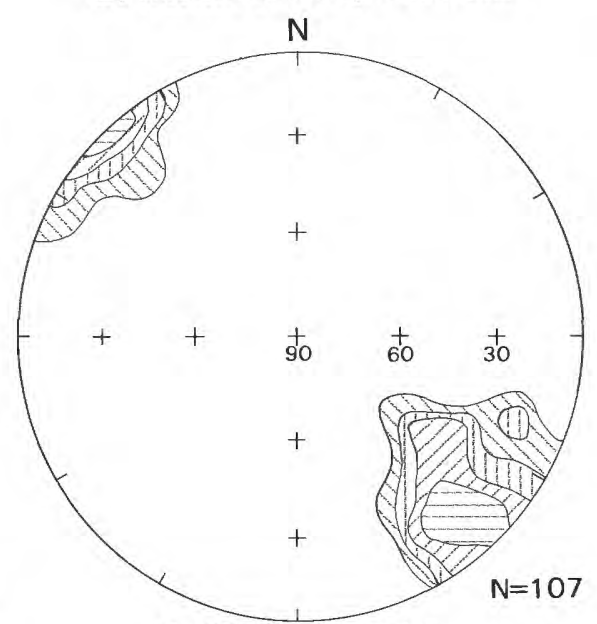

E, Wilkins Mountains

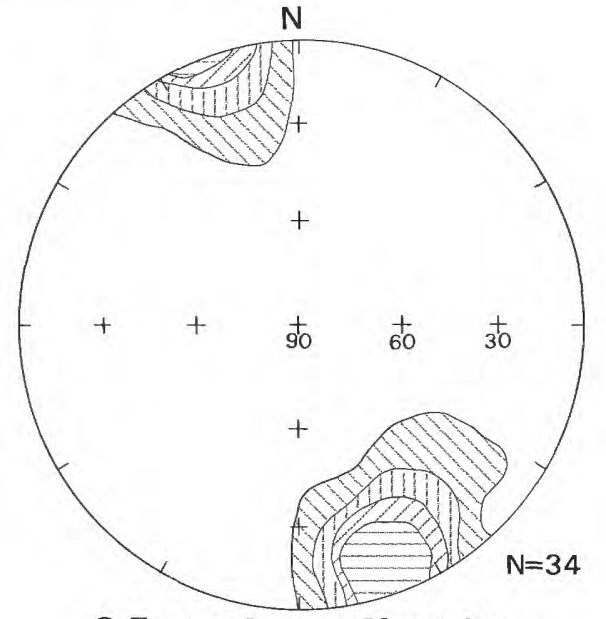

C, Eastern Sweeney Mountains

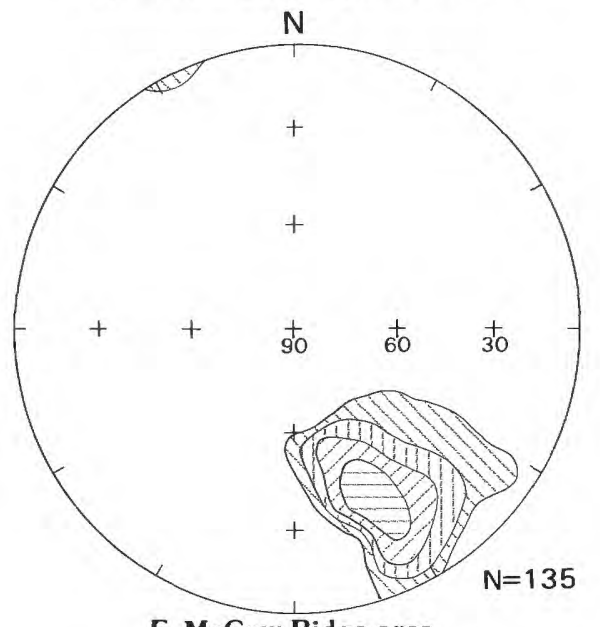

F, McCaw Ridge area

FIGURE 13.-Contoured equal-area projections of poles to axial-plane cleavage $\left(\mathrm{S}_{1}\right)$ in the Latady and Mount Poster Formations for the six areas shown on figure 3 . Successive contours are at $2,4,6$, and 8 percent of poles per 1 percent area. $N$ is number of observations.
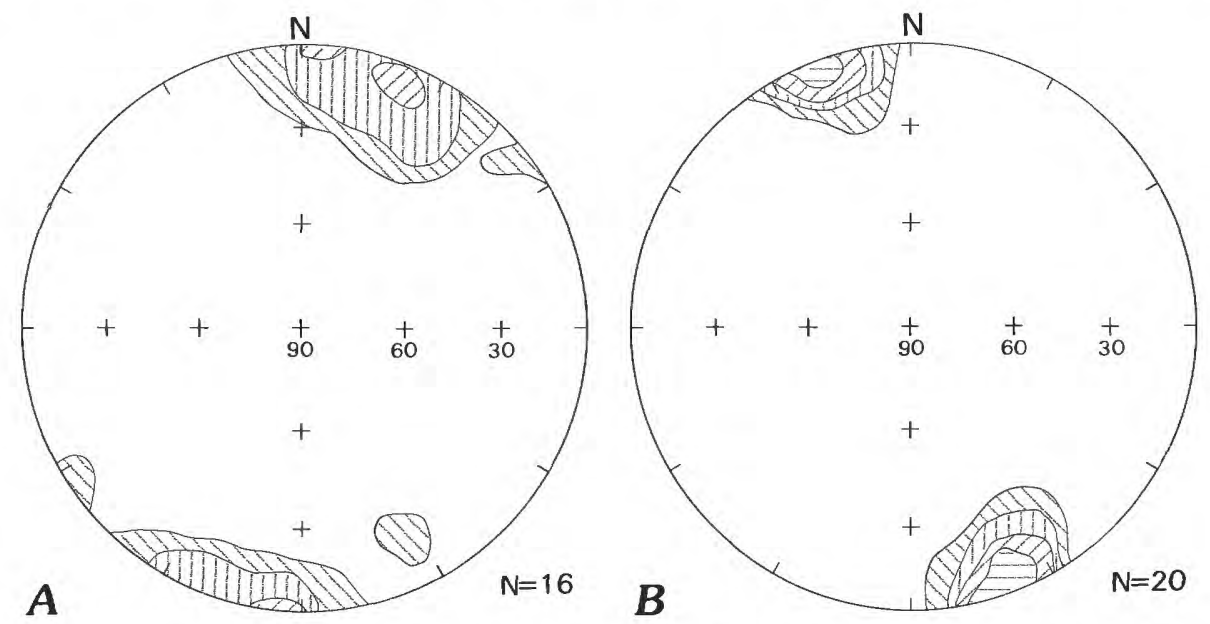

FIGURE 14.-Contoured equal-area projections of poles to fracture cleavage in massive rhyodacite porphyry of the Mount Poster Formation for two of the six areas shown on figure 3. $A$, western Sweeney Mountains (area $B$ of fig. 3); $B$, eastern Sweeney Mountains (area $C$ of fig. 3). Volcanic rocks of eastern Ellsworth Land are not commonly cleaved and so are not shown. Successive contours are at $2,4,6$, and 8 percent of poles per 1 percent area. $\mathrm{N}$ is number of observations. 


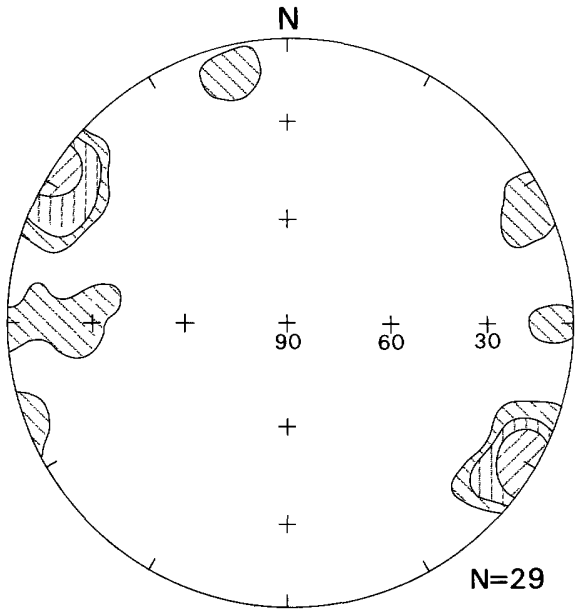

$A$, Eastern Ellsworth Land

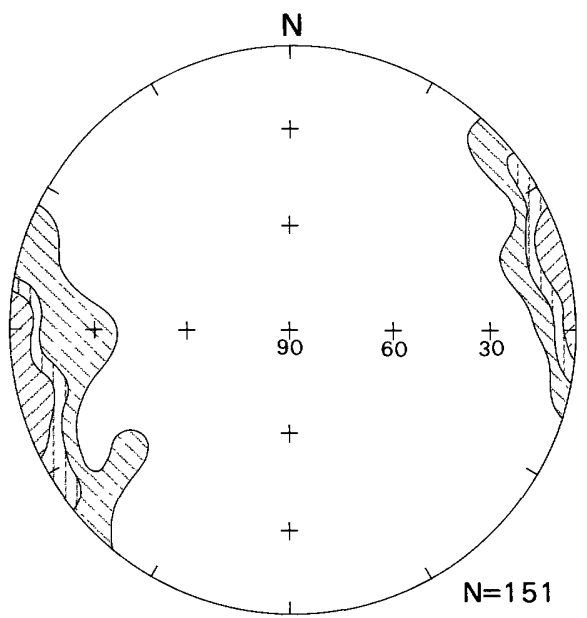

$D$, Hauberg Mountains

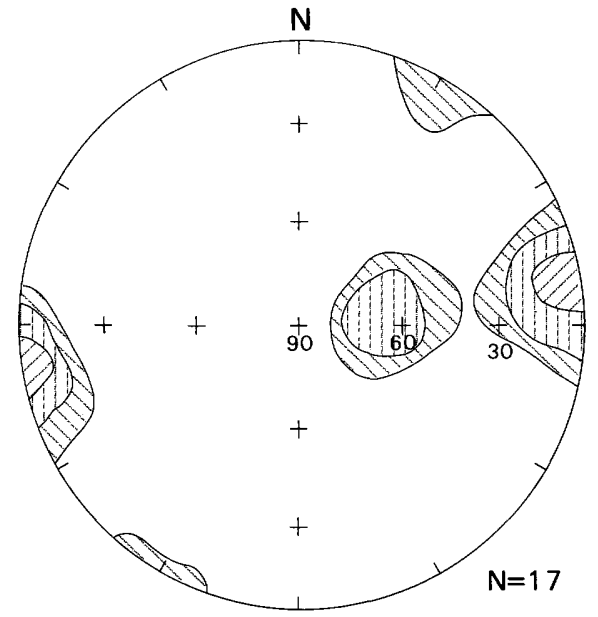

$B$, Western Sweeney Mountains

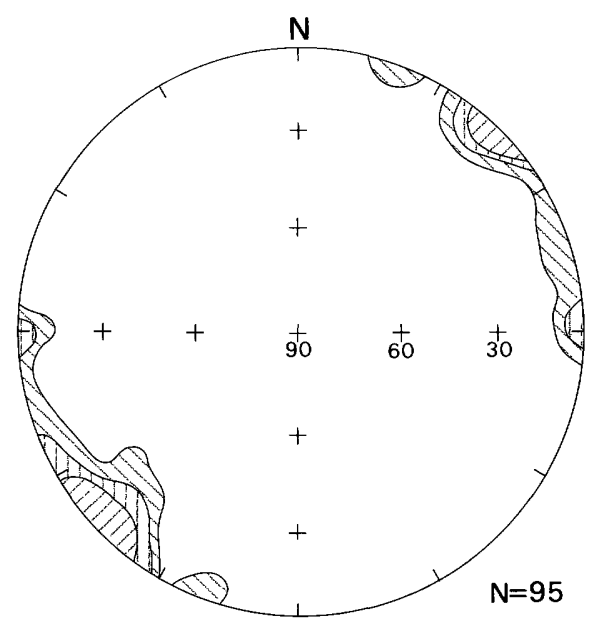

E, Wilkins Mountains

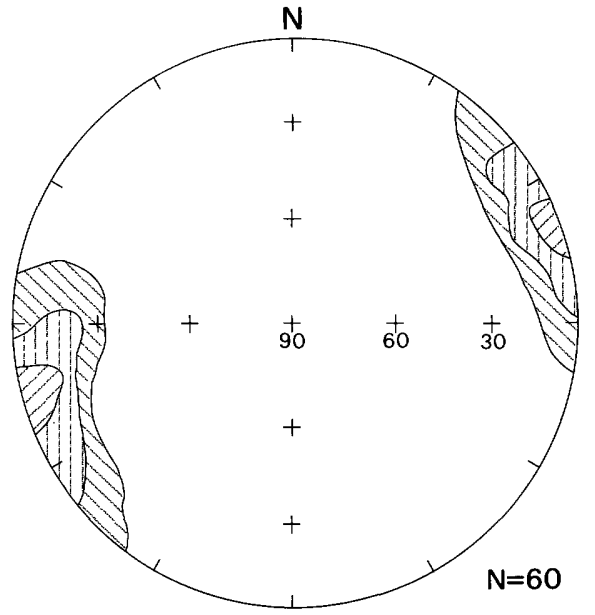

$C$, Eastern Sweeney Mountains

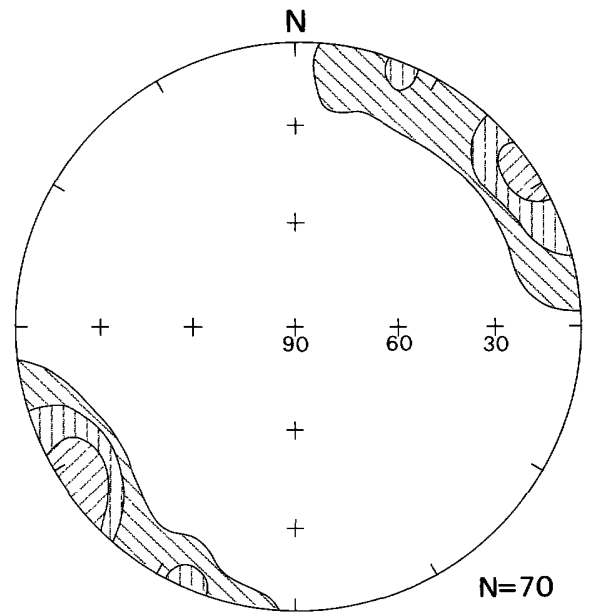

F, McCaw Ridge area

FIGURE 15.-Contoured equal-area projections of poles to joint surfaces in folded layered rocks of the Latady Formation for the six areas shown on figure 3. Successive contours are at 2,4 , and 6 percent of poles per 1 percent area. $\mathrm{N}$ is number of observations.
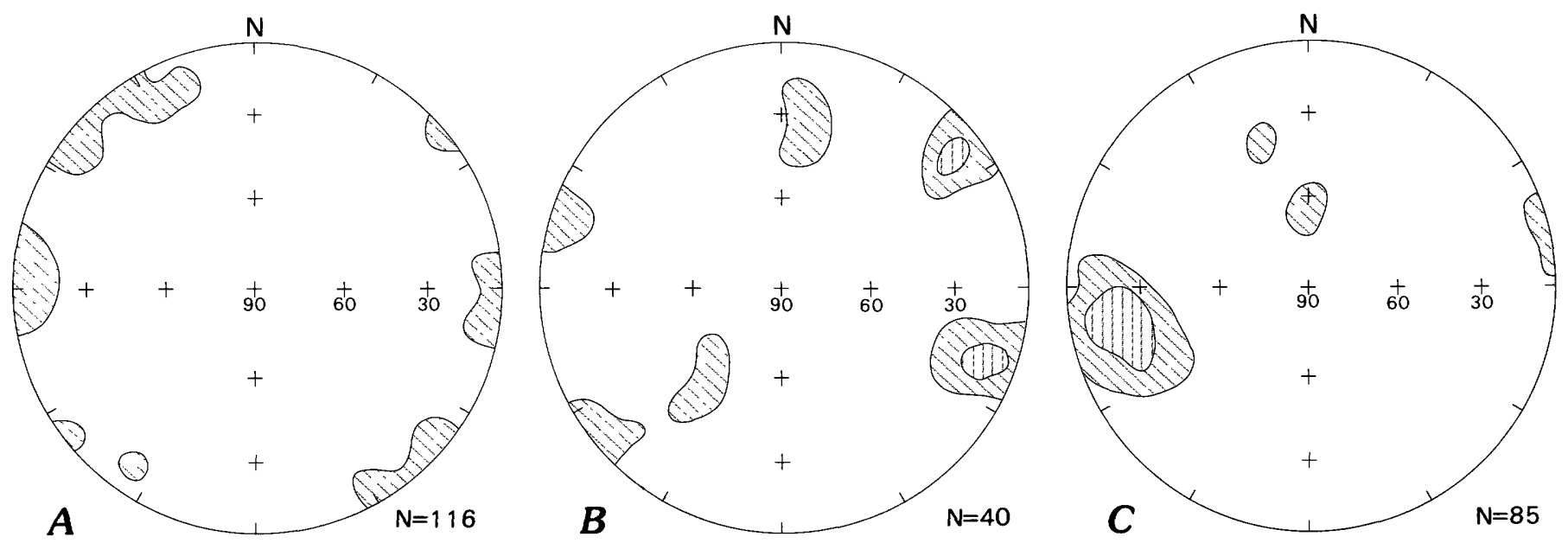

FIGURE 16.-Contoured equal-area projections of poles to joint surfaces in massive rhyodacite porphyry and layered volcanic rocks of the Mount Poster Formation for three of the six areas shown on figure 3. $A$, eastern Ellsworth Land; $B$, western Sweeney Mountains; $C$, eastern Sweeney Mountains. Successive contours are at 2 and 4 percent of poles per 1 percent area. $\mathrm{N}$ is number of observations. 
(fig. 15). Quartz also locally infills slaty cleavage $\left(S_{1}\right)$ planes, and irregular quartz-filled fractures are more densely grouped in the hinge zone of some folds, indicating that at least some mineralization is synchronous with or postdates folding.

\section{STRUCTURES OF THE LASSITER COAST INTRUSIVE SUITE}

\section{JOINTS}

Joint directions in plutonic rocks of the Lassiter Coast Intrusive Suite (Vennum and Rowley, 1986) in the Orville Coast (fig. 18B), excluding data from eastern Ellsworth Land (area $A$ of fig. 3), are almost randomly oriented, except for a slight preference towards being vertical. However, although joint directions in the 107-Ma (Halpern, 1967; age corrected for new decay constants of Steiger and Jäger, 1977) Merrick Mountains diorite of eastern Ellsworth Land (Vennum and Laudon, 1988) (fig. 18A) are scattered, they do suggest a preferred joint orientation of about N. $20^{\circ} \mathrm{W}$.

In contrast to the general lack of preferred orientation of joints in plutonic rocks of the Orville Coast, joint orientations in rocks of the same plutonic suite in the Lassiter Coast are strongly oriented parallel to the regional extension-joint direction (Kellogg and Rowley, 1974; unpub. data). This preferred orientation in the Lassiter Coast area is particularly well defined by open joints that contain iron-oxide minerals (probably formerly pyrite), chlorite, and quartz. Joints of this orientation are probably the conduits through which

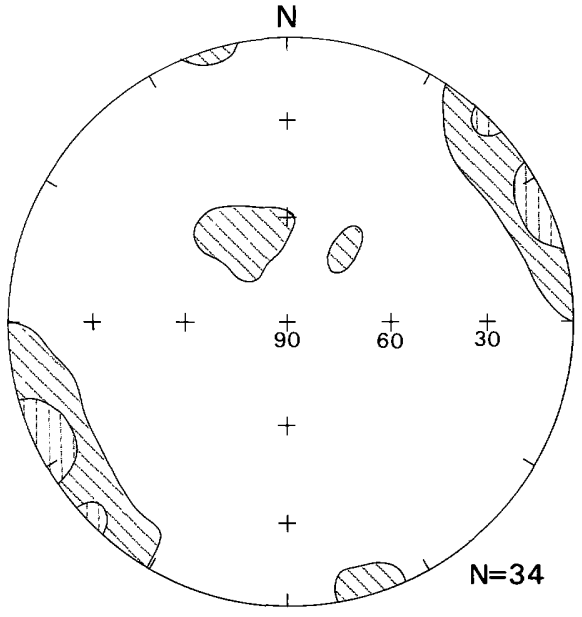

FIGURE 17.-Contoured equal-area projection of poles to quartz-filled fractures in sedimentary rocks of the Latady Formation, Orville Coast (combined plot of data for areas $B-F$ of fig. 3); no data were gathered for eastern Ellsworth Land (area $A$ of fig. 3), although quartz-filled fractures are common there. Successive contours are at 2 and 4 percent of poles per 1 percent area. $\mathrm{N}$ is number of observations.

hydrothermal fluids ascended during formation of copper occurrences in the Copper Nunataks of the Lassiter Coast (Rowley and others, 1977) and the Sky-Hi Nunataks and Merrick Mountains of eastern Ellsworth Land (Rowley and others, 1988) (fig. 3).

The fact that joint orientations are better defined in plutonic rocks of the Lassiter Coast than in similar-age
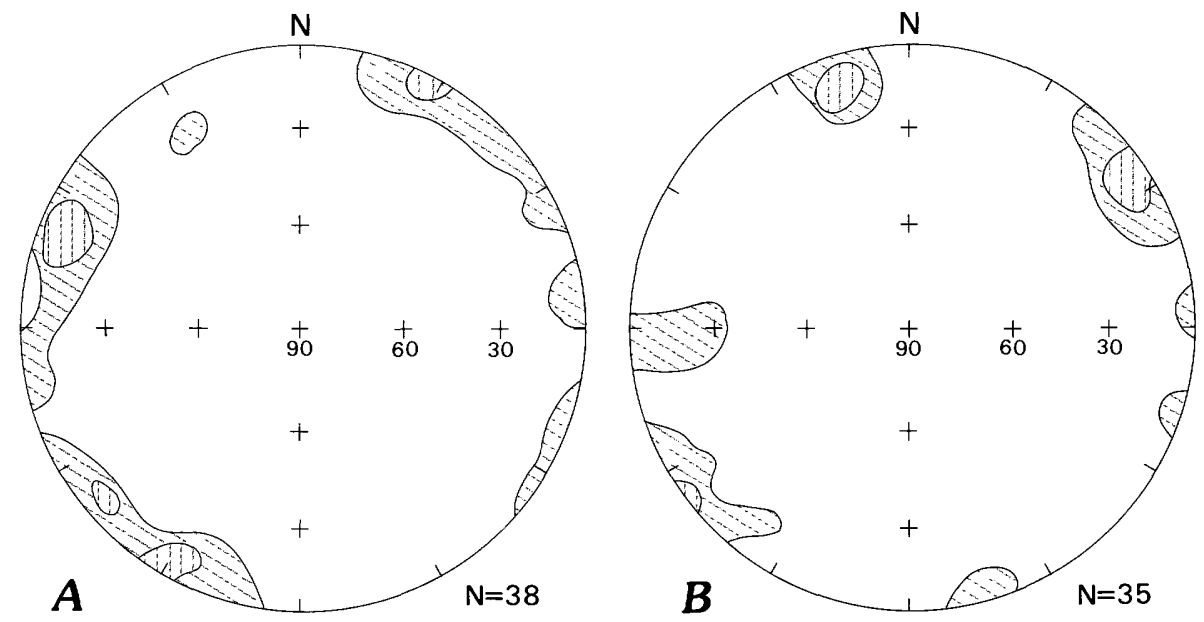

FIgure 18.-Contoured equal-area projections of poles to joint surfaces in $A$, Merrick Mountains diorite stock, eastern Ellsworth Land (area $A$ of fig. 3) and $B$, all stocks of the Orville Coast (combined plot of data for areas $B-F$ of fig. 3 ). Successive contours are at 2 and 4 percent of poles per 1 percent area. $\mathrm{N}$ is number of observations. 
(Pankhurst and Rowley, in press) rocks of the Orville Coast suggests that cross-peninsular compression, culminating during the Palmer Land deformational event, lingered longer in the Lassiter Coast than in the Orville Coast.

\section{DIKES}

Basaltic to rhyolitic dikes of the Lassiter Coast Intrusive Suite cut both plutons and surrounding sedimentary and volcanic rocks throughout the Orville Coast and eastern Ellsworth Land. K-Ar ages from the Lassiter Coast (Mehnert and others, 1975) and crosscutting relationships indicate that the dikes are related to late stages of pluton emplacement, which occurred about $100 \mathrm{Ma}$. This age is supported by paleomagnetic data from the Lassiter Coast (Kellogg, 1980), where dikes similar in composition to those of the Orville Coast and eastern Ellsworth Land have almost identical paleomagnetic directions to those for the approximately 100-Ma plutonic rocks of the Lassiter Coast. Undated aplite and subordinate pegmatite dikes, related to late plutonic activity, cut plutons with random orientations (data not shown).

Dike orientations in the Orville Coast and eastern Ellsworth Land (fig. 19) suggest an extension direction that is considerably different from that indicated from joints in sedimentary rocks from the same area (fig. 15). Most dikes, of which more than half (44 of 77 observations) are in eastern Ellsworth Land (area $A$ of fig. 3),

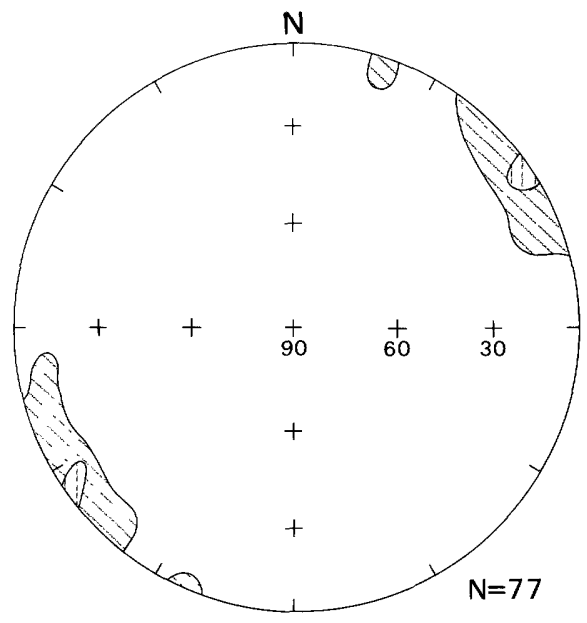

Figure 19.-Contoured equal-area projection of poles to dike orientations, Orville Coast and eastern Ellsworth Land (combined plot of data for areas $A-F$ of fig. 3). More than half of dike orientations (44 of 77) are from eastern Ellsworth Land (area $A$ of fig. 3). Successive contours are at 2 and 4 percent of poles per 1 percent area. $\mathrm{N}$ is number of observations. are vertical and strike north-northwest, reflecting eastnortheast extension. Joint directions in sedimentary rocks from eastern Ellsworth Land suggest westnorthwest extension during folding (fig. 15A). This large difference in extension direction probably reflects a change in the principal stress trajectories between the time the Palmer Land deformational event culminated and the time the dikes intruded; that is, between sometime in the Early Cretaceous (140-120 Ma?) and about $100 \mathrm{Ma}$. This change in the stress trajectories may have been from a state of pure shear during crosspeninsular compression to one of right-lateral simple shear induced by early movement along a large, northwest-trending, right-lateral fault system (Ellsworth fault of Ford, 1972), which may bound the southern margin of the peninsula (see section entitled "Southern tectonic boundary of the Orville Coast"). In eastern Ellsworth Land, the fault system would have produced north- to north-northwest-oriented extension planes along which dikes intruded.

\section{HIGH-ANGLE FAULTS}

Numerous high-angle faults of small displacement were observed cutting the Latady Formation in the Orville Coast and eastern Ellsworth Land (figs. 8 and 20). In contrast, high-angle faults were rarely seen in the Lassiter Coast to the north, although high-angle faults

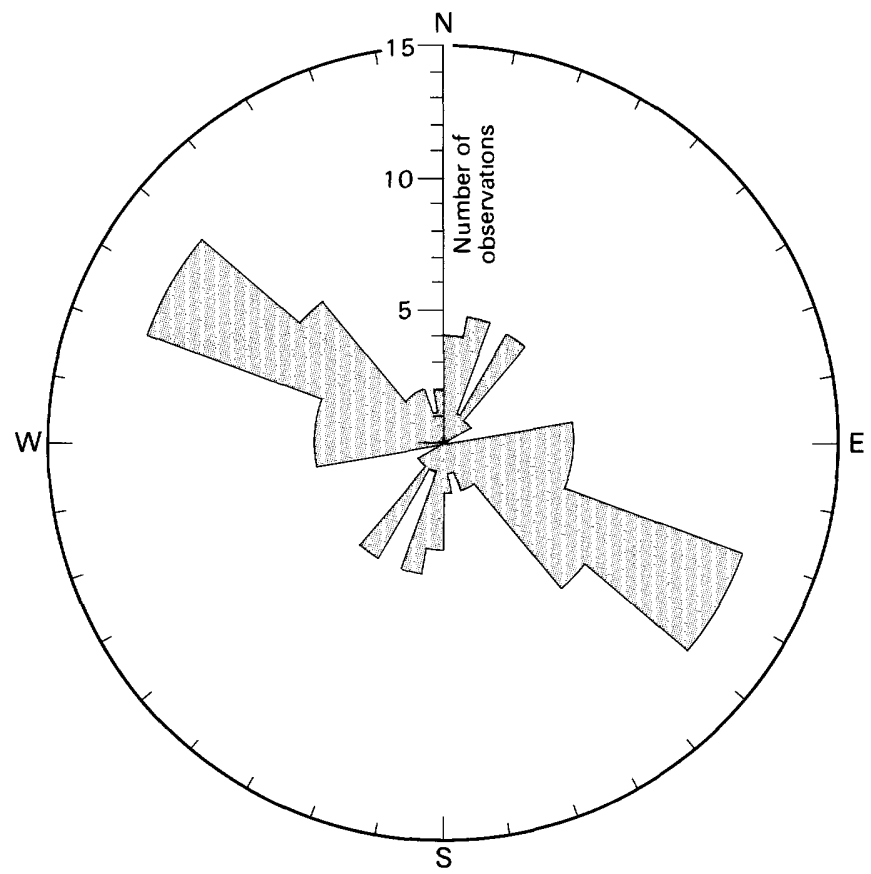

FIGURE 20.-Rose diagram of strike directions of all observed highangle faults cutting the Latady Formation in the Orville Coast and eastern Ellsworth Land. Of 69 observations, 15 are from Laudon and others (1970). 
oriented parallel to the extension-joint direction and associated with hydrothermally altered and coppermineralized rocks were mapped in the Copper Nunataks of the Lassiter Coast (Rowley and others, 1977). Highangle faults cutting sedimentary rocks in the Orville Coast and eastern Ellsworth Land show as much as several tens of meters of apparent strike-slip movement where displacement could be measured. The predominant strike direction for faults throughout the Orville Coast and eastern Ellsworth Land is about N. $70^{\circ} \mathrm{W}$. (Kellogg and Rowley, in press) (fig. 20), although a smaller group of fault orientations occurs at about right angles to the larger set. In the predominant set, 14 of 69 faults show discernible offset in an apparent rightlateral sense; three others show apparent left-lateral offset. These relationships suggest a regional right-lateral shear regime along west-northwest trends.

\section{PALEOMAGNETIC EVIDENGE FOR RELATIVE ROTATION ABOUT VERTICAL AXES IN THE SWEENEY AND HAUBERG MOUNTAINS}

The paleomagnetic declinations from middle Cretaceous plutons in the Orville Coast and eastern Ellsworth Land are rotated clockwise by an average of $50^{\circ}$ relative to the paleomagnetic direction from coeval plutons in the Lassiter Coast (Kellogg, 1980). Rotation of the Orville Coast and eastern Ellsworth Land poles was thought to be due to drag along the right-lateral Ellsworth fault of Ford (1972)-the Ellsworth fault system of this report-which may bound the southern Antarctic Peninsula (see section entitled "Southern tectonic boundary of the Orville Coast").

The suggestion that paleomagnetic vectors were rotated by drag along the Ellsworth fault system (Kellogg, 1980) was challenged by Watts and others (1984). They contended that the difference in direction between middle Cretaceous plutonic rocks of the Lassiter Coast and plutonic rocks from the Orville Coast and eastern Ellsworth Land was due to apparent polar wander rather than to tectonic rotation. This contention was based on an overly literal interpretation of geochronologic data of Kellogg (1980); these data were used to infer that the studied rocks of the Orville Coast and eastern Ellsworth Land were about $8 \mathrm{~m} . \mathrm{y}$. older than other ("unrotated") intrusive rocks in the southern part of the peninsula. We feel, however, that the available geochronologic data do not support this conclusion.

Table 1 presents previously published and new paleomagnetic and geochronologic data for the Behrendt and Merrick Mountains; table 2 summarizes all of the paleomagnetic and geochronologic data for middle Cretaceous rocks from the Antarctic Peninsula. These data point to two major conclusions. Firstly, uncertainties in $\mathrm{K}-\mathrm{Ar}$ and $\mathrm{Rb}-\mathrm{Sr}$ dates (Halpern, 1967; Farrar and others, 1982; Pankhurst and Rowley, in press) of plutons sampled for paleomagnetic study do not support the notion that ages are significantly different between the plutonic rocks of the Orville Coast and eastern Ellsworth Land and other middle Cretaceous plutons with "unrotated" declinations. Secondly, it appears that all plutons with clockwise-rotated paleomagnetic declinations are in the Sweeney and Hauberg Mountains; paleomagnetic directions from eastern Ellsworth Land are not significantly different from "unrotated" localities farther north on the peninsula (table 2). This implies, therefore, that oroclinal bending occurred only in the Orville Coast.

A late Early Cretaceous (110-95 Ma) paleomagnetic pole is well established from numerous localities on the Lassiter Coast (Kellogg and Reynolds, 1978) (table 2 and point LC on fig. 21). A 111- to 104-Ma pole is also determined for the Shetland Islands from the data of Watts and others (1984) (table 2 and point SI on fig. 21) and is in close agreement with the Lassiter Coast pole.

The only dated plutons from the Orville Coast are from the Sweeney Mountains. They yield a $\mathrm{K}-\mathrm{Ar}$ age on biotite of $107 \pm 4 \mathrm{Ma}$ from the granite of Mount Smart (Rowley and others, 1988), a Rb-Sr age of $104 \pm 11$ Ma from the Mount Edwards pluton (Pankhurst and Rowley, in press), and a Rb-Sr age of 112.6土 1.2 Ma from the diorite of Hagerty Peak (Pankhurst and Rowley, in press). The combined mean paleomagnetic pole from 113- to 104-Ma plutons of the Sweeney Mountains (Kellogg, 1980; localities Ke101 (Mount Smart), Ke154 and L31 (Mount Edwards), and Ke158 (Hagerty Peak)) is lat $60^{\circ} \mathrm{S}$., long $177^{\circ} \mathrm{W}$. $\left(\alpha_{95}\right.$ (the semiangle of the cone of 95 -percent confidence) $=9^{\circ}$, calculated from site-mean directions). Although plutons and dikes of the Hauberg Mountains are undated, paleomagnetic results from these rocks are similar to those from the Sweeney Mountains; the mean pole from three localities in the Hauberg Mountains (Kellogg, 1980; localities Ke127, C15, and Ro410) is lat $71^{\circ} \mathrm{S}$., long $134^{\circ} \mathrm{W} .\left(\alpha_{95}=7^{\circ}\right)$. Eleven dated and undated localities (72 samples) from the Sweeney and Hauberg Mountains give a mean pole of lat $65^{\circ} \mathrm{S}$., long $165^{\circ} \mathrm{W}$. $\left(\mathrm{A}_{95}\right.$ (the semiangle of the cone of 95-percent confidence about the virtual geomagnetic pole) $=9^{\circ}$ ), which is not significantly different from the pole determined from dated plutons. The combined pole from the 11 localities of the Sweeney and Hauberg Mountains is shown on figure 21 (point labeled $\mathrm{SH}$ ).

Dated and undated paleomagnetic rocks from the Behrendt and Merrick Mountains of eastern Ellsworth 
TABLE 1.-Paleomagnetic and geochronologic data from mid-Cretaceous rocks from the Behrendt and Merrick Mountains, eastern Ellsworth Land

[Three localities (Ke237, Ke239, Ke240) are new; two localities (Ke189, Ke190) are from Kellogg (1980). N, number of sites; (n), total number of samples; demagnetization field (in milliteslas) is that at which the paleomagnetic direction is chosen; $D$, mean declination in degrees, clockwise from true north; $I$, mean inclination in degrees, negative upward; $\alpha_{95}$, semiangle of cone of 95-percent confidence; $R$, magnitude of vector sum of the $N$ unit vectors; $d m$ and dp, semimajor and semiminor axes, respectively, of oval of 95 -percent confidence. Leaders $(--)$, not calculated]

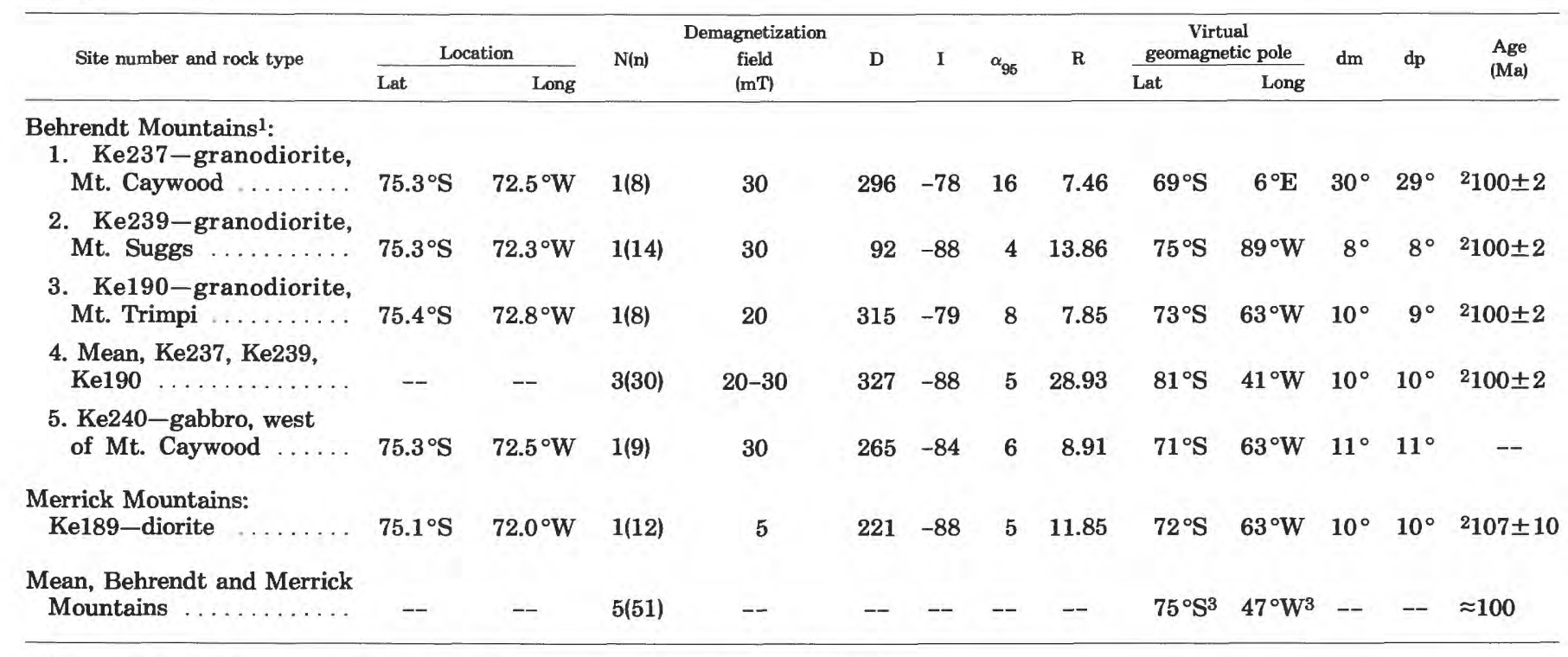

${ }_{2}^{1}$ Numbers 1-5 refer to corresponding numbers used on figure 21 to plot virtual geomagnetic poles.

$2_{\mathrm{Rb}-\mathrm{Sr}}$ ages (Halpern, 1967) corrected for new decay constants of Steiger and Jäger (1977).

${ }^{3} \mathrm{~A}_{95}$ (Semiangle of cone of 95 -percent confidence around mean virtual geomagnetic pole) $=5^{\circ}$.

TABLE 2.-Paleomagnetic and geochronologic data from mid-Cretaceous rocks from the Antarctic Peninsula

[N, number of sites; $(\mathrm{n})$, total number of samples; $\mathrm{D}$, mean declination in degrees, clockwise from true north; $\mathrm{I}$, mean inclination in degrees, negative upward; $\mathrm{A}_{95}$, semiangle of cone of 95-percent confidence around mean virtual geomagnetic pole; $\left(\alpha_{95}\right)$, semiangle of cone of 95-percent confidence around mean of site-mean directions. Leaders (--), not calculated]

$\begin{array}{llllllll}\text { Locality }^{1} & \text { Age (Ma) } & \text { N(n) } & \text { D } & \text { I } & A_{95}\left(\alpha_{95}\right) & \frac{\text { Paleomagnetic pole }}{\text { Lat }}\end{array}$

Sweeney and Hauberg Mountains:

Sweeney Mountains, dated localities

(Ke101, Ke154, Ke158, L31) ${ }^{2} \ldots \ldots$

Sweeney Mountains, all localities (Dated localities and undated localities Ke141, Ke142, Ke145, Ke157) $4 \ldots \ldots \ldots \ldots$

Hauberg Mountains, (Undated localities

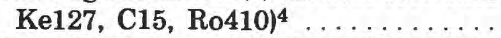

Mean, Sweeney and Hauberg Mountains, all localities (point $\mathrm{SH}$, fig. 21) ....

Eastern Ellsworth Land, mean from table

1 (point EE, fig. 21) ............

Lassiter Coast:

All dated intrusives (Crowell pluton,

M206, M307, M308, Ke39) ${ }^{6} \ldots \ldots$.

All intrusives (point LC, fig. 21 .... .

$\begin{array}{lrrrrrr}2,3113-104 & 4(24) & 53 & -69 & \left(9^{\circ}\right) & 60^{\circ} \mathrm{S} & 177^{\circ} \mathrm{W} \\ \approx 115-100 & 8(52) & 55 & -71 & \left(6^{\circ}\right) & 61^{\circ} \mathrm{S} & 173^{\circ} \mathrm{W} \\ 115 ?-100 ? & 3(20) & 73 & -81 & \left(7^{\circ}\right) & 71^{\circ} \mathrm{S} & 134^{\circ} \mathrm{W} \\ 5 \approx 108 & 11(72) & -- & -- & 9^{\circ} & 65^{\circ} \mathrm{S} & 165^{\circ} \mathrm{W} \\ \approx 100 & 5(51) & -- & -- & 5^{\circ} & 75^{\circ} \mathrm{S} & 47^{\circ} \mathrm{W} \\ & & & & & & \\ 3,7109-96 & 5(28) & -- & -- & 5^{\circ} & 85^{\circ} \mathrm{S} & 37^{\circ} \mathrm{W} \\ 8 \approx 110-95 & 17(96) & -- & -- & 12^{\circ} & 87^{\circ} \mathrm{S} & 131^{\circ} \mathrm{W} \\ 111-104 & 4(29) & 2 & -68 & 7^{\circ} & 79^{\circ} \mathrm{S} & 126^{\circ} \mathrm{E}\end{array}$

Shetland Islands ${ }^{9}$, dated rocks only

(point SI, fig. 21) ................

\footnotetext{
${ }^{1}$ Numbers with letter prefix are site-locality numbers

2Rowley and others (1988); K-Ar ages.

3 Pankhurst and Rowley (in press).

${ }^{4}$ Kellogg (1980).

${ }^{5}$ Age estimated from four dated plutons.
}

${ }^{6}$ Kellogg and Reynolds (1978).

${ }^{7}$ Mehnert and others (1975); K-Ar age on biotite corrected for new decay constants of Steiger and Jäger (1977).

8 Age range estimated from five dated plutons.

${ }^{9}$ Watts and others (1984). 


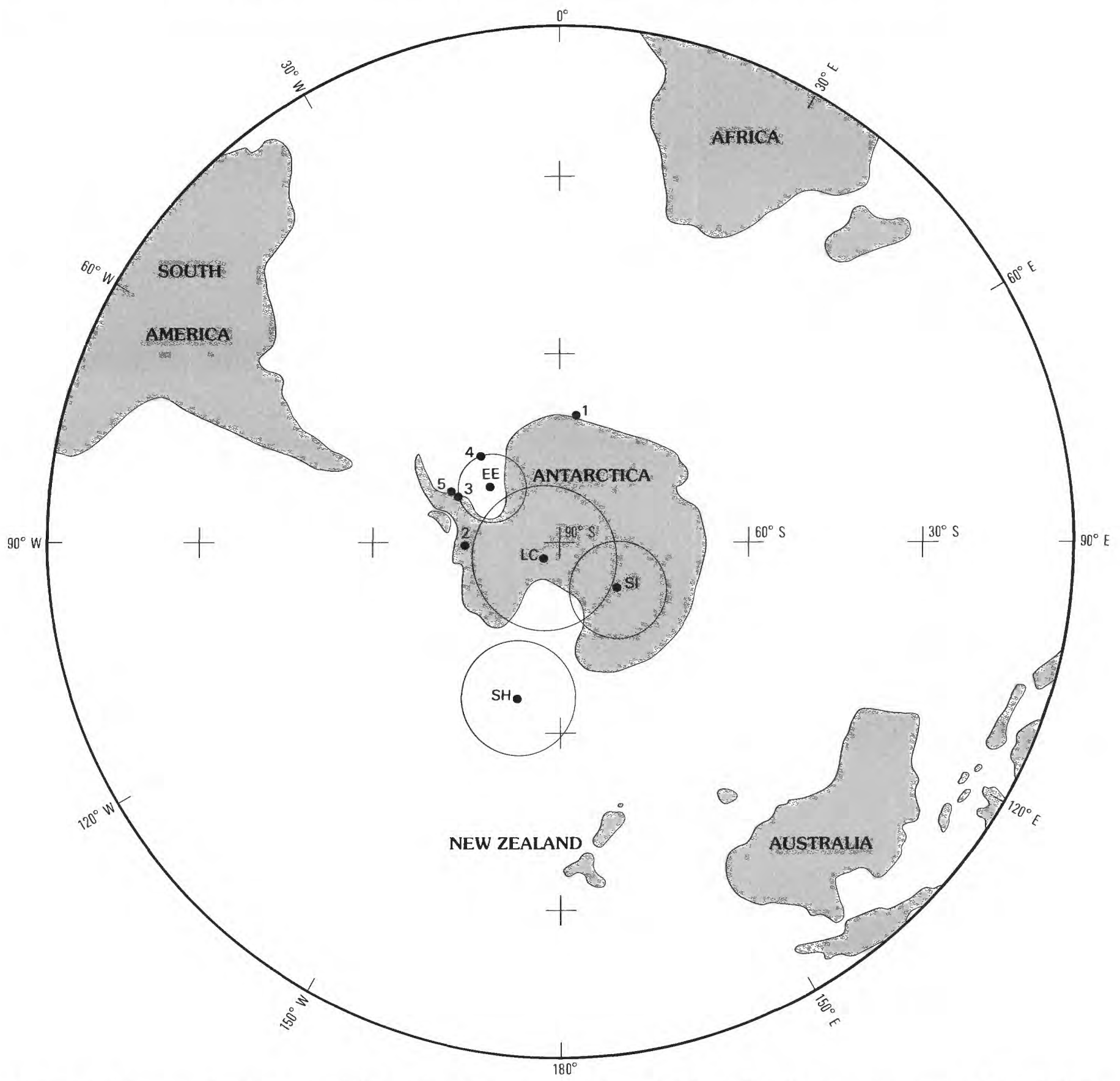

FIGURE 21.-Paleomagnetic poles, surrounded by circles of 95-percent confidence, for 111- to 103-Ma plutons from eastern Ellsworth Land (EE; table 2), Sweeney and Hauberg Mountains, Orville Coast (SH; table 2), Lassiter Coast (LC; table 2), and Shetland Islands (SI; table 2). Numbers refer to site-mean poles determined from the Behrendt and Merrick Mountains, eastern Ellsworth Land (table 1).

Land define poles (tables 1 and 2 and point EE on fig. 21) that are significantly different from those of the Sweeney and Hauberg Mountains and are more consistent with the mean poles from the Lassiter Coast and Shetland Islands (table 2 and points LC and SI on fig. 21). The Behrendt Mountains pluton has a $\mathrm{Rb}-\mathrm{Sr}$ age of $100 \pm 2 \mathrm{Ma}$, and the Merrick Mountains diorite has a Rb-Sr age of $107 \pm 10 \mathrm{Ma}$ (Halpern, 1967; ages corrected for new decay constants of Steiger and Jäger,
1977). Kellogg (1980) reported two virtual geomagnetic poles for localities in the Behrendt and Merrick Mountains plutons (table 1). Three previously unreported poles, of which two are from localities in the Behrendt Mountains pluton and another is from a locality in an undated gabbro in the Behrendt Mountains, are also presented here (table 1).

Demagnetization diagrams for samples from dioritic inclusions in the northern Behrendt Mountains pluton 

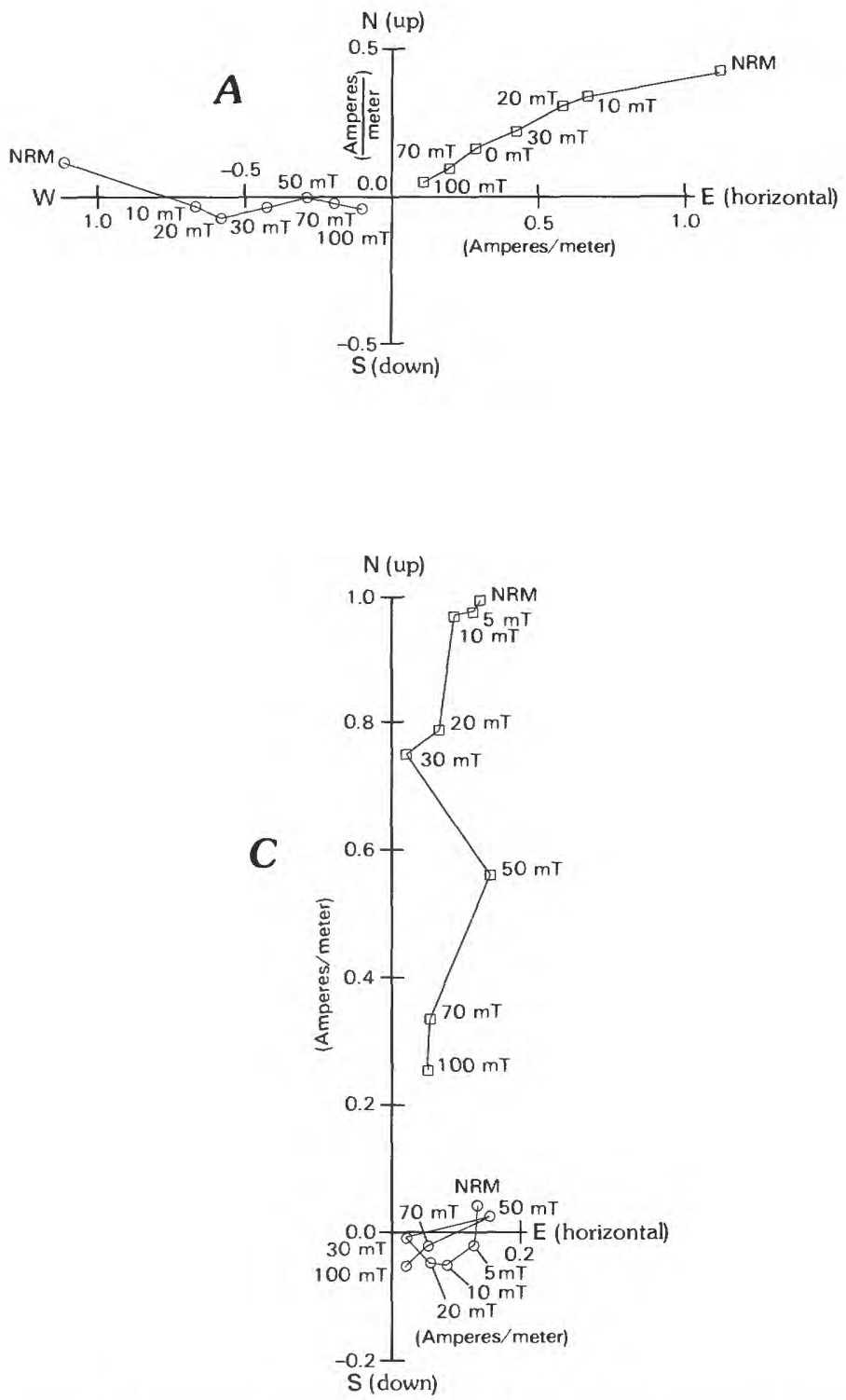
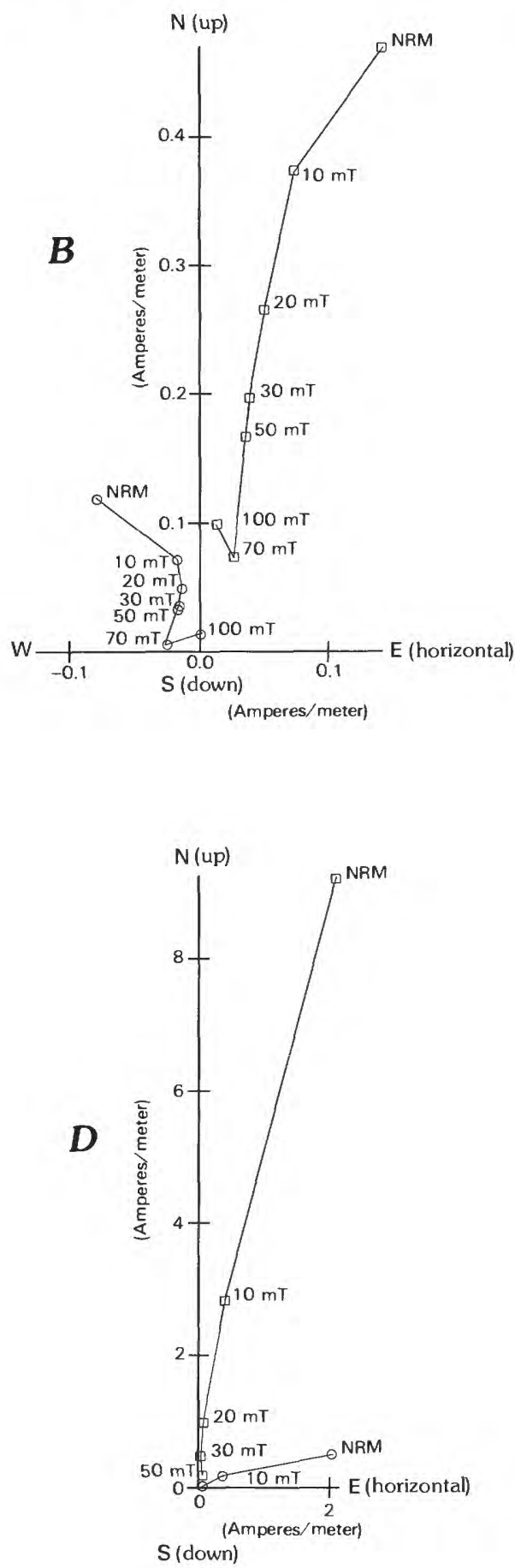

FIGURE 22.-Demagnetization diagrams for four selected samples from the Behrendt Mountains. Diagrams $A-C$ show results for samples Ke237A, Ke237I, and Ke239A, respectively, from the northern Behrendt Mountains pluton; diagram $D$ shows results for sample Ke240C from an undated gabbro on west side of the northern Behrendt Mountains pluton. "Ke" and the next three numbers designate the site; the last letter designates the sample from that site. Each diagram displays two views of paleomagnetic vector at each demagnetizing level: circles represent projection of paleomagnetic vector onto horizontal plane $(\mathrm{N}, \mathrm{S}, \mathrm{E}$, and $\mathrm{W}$ axes); squares represent paleomagnetic vector on vertical plane containing paleomagnetic vector (up, down, and horizontal axes). $\mathrm{NRM}$, natural remanent magnetization; $\mathrm{mT}$, milliteslas.

(figs. 22A-C) demonstrate that the remanence remaining after demagnetization at inductions above $20 \mathrm{mT}$ (milliteslas) is, in almost all cases, single component. One sample (Ke237A, fig. 22A), although showing convincing single-component magnetization, has an unusually shallow inclination of unknown origin. Another sample 
(Ke237I, fig. 22B) appears to have a small secondary component at high demagnetizing inductions that is probably due to the acquisition of a component of anhysteretic remanent magnetization, an artifact of the demagnetization process itself. Some scatter in the data for sample Ke239A (fig. 22C) may be caused by acquisition of viscous remanence during measurement; such behavior is typical of the majority of samples collected from more-felsic plutonic rocks, regardless of whether the samples were from inclusions or from coarser and more-felsic host rock. It should be noted, however, that within the Behrendt Mountains pluton the mean directions for each sampling locality at each demagnetization level do not show a significant or consistent change in direction. This indicates that viscous remanence acquired during demagnetization is randomly oriented.

Sample Ke240C, from an undated gabbro body on the west side of the Behrendt Mountains pluton, shows strong evidence for single-component magnetization (fig. 22D).

It is clear that the paleomagnetic pole from the Sweeney and Hauberg Mountains is significantly different from all other late Early Cretaceous paleomagnetic poles from the Antarctic Peninsula at the 95-percent confidence level (fig. 21). Because of age equivalency of the rocks, the pole differences indicate that tectonic rotation has displaced the Sweeney-Hauberg Mountains pole from the others. Clockwise rotation of the Sweeney-Hauberg Mountains pole-by about $50^{\circ}-60^{\circ}$ about a vertical axis since the middle Cretaceous-is necessary to account for the pole differences. Although the rotated area includes the Sweeney and Hauberg Mountains, its total extent is unknown.

\section{DISCUSSION}

\section{THE LATADY BASIN AS A BACK-ARC RIFT}

Most geologic features of the Orville Coast and eastern Ellsworth Land are related to the evolution of a magmatic arc between Middle Jurassic and Late Cretaceous time (fig. 23). If the predominantly marine Latady Formation occupies a back-arc basin behind the volcanic rocks of the Mount Poster Formation (Suárez, 1976), then
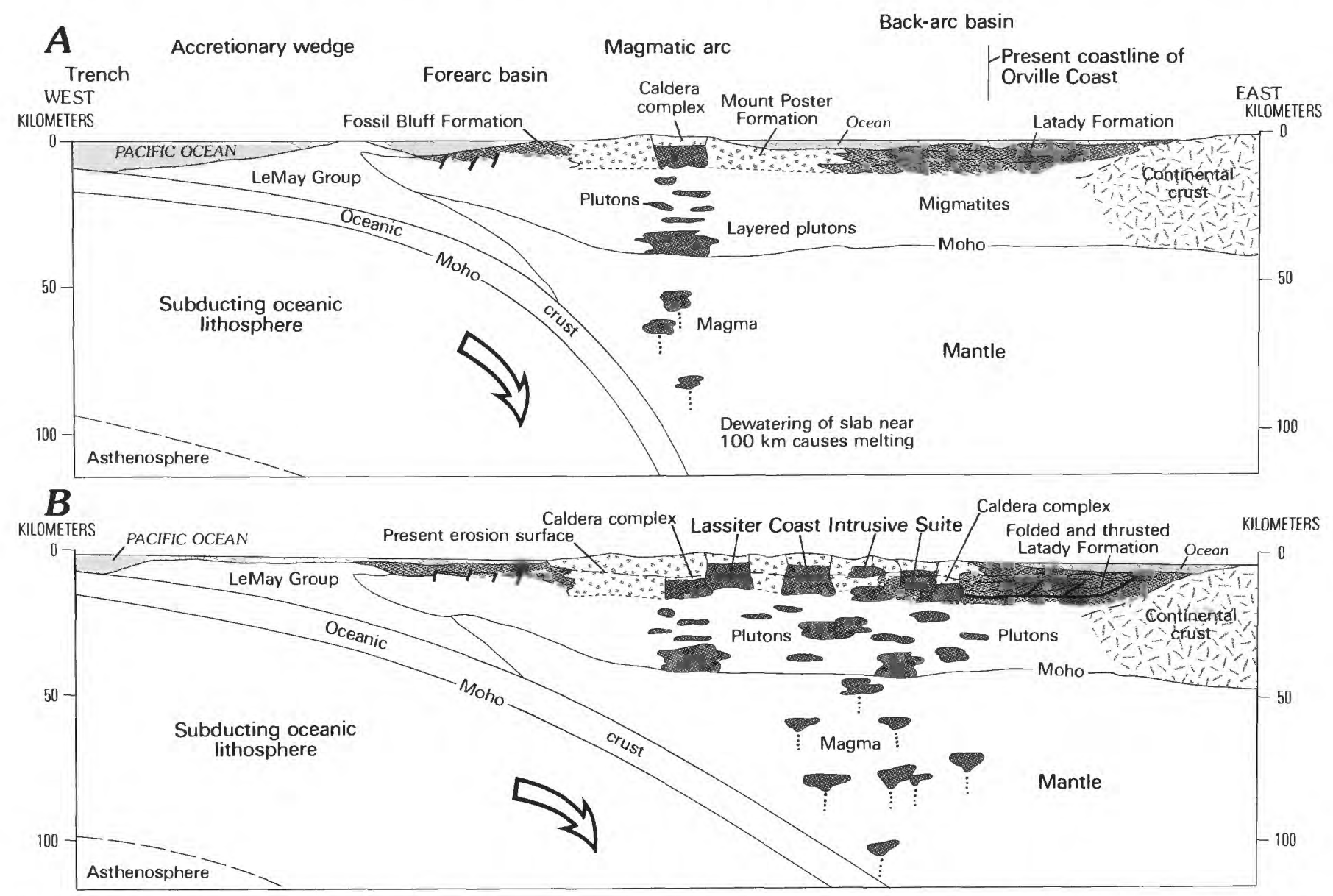

FIGURE 23.-Schematic cross section, oriented approximately along line A-A' on figure 24, showing major tectonic elements in $A$, Late Jurassic time and $B$, middle Cretaceous time. Based in part on model for Sunda arc in the East Indies (Hamilton, 1987). 
the Latady Formation, as well as the Mount Hill Formation to the north, may have been deposited in a basin formed by normal faulting related to back-arc spreading, a common process in developing magmatic arcs (Hamilton, 1985, 1987).

Evidence for a back-arc-rift origin for the Latady basin is far from unequivocal. Mesozoic rift structures have not been identified in the study area or in the Lassiter Coast to the north (Kellogg and Rowley, 1974; Rowley and Williams, 1982), although they have been inferred in the Black Coast in northern Palmer Land (Storey and others, 1987). Gabbroic plutons in northern Palmer Land and some ductile, north-trending, highangle faults in central Palmer Land may represent extensional development of a back-arc-rift basin in Middle Jurassic to earliest Cretaceous time (Meneilly and others, 1987). In the central Black Coast, additional sequences of locally sheared basalt flows (amygdaloidal basalt of Kamenev Nunatak) and large, sheared alkalic gabbro bodies that may be the source plutons of the basalts (Rowley and others, 1987; Storey and others, 1987) also suggest an extensional environment.

The significance and age of the shearing in the Black Coast, however, is still uncertain. Kinematic indicators within the northerly striking, ductile, high-angle shear zones that cut the basalt and alkalic gabbro plutons in the central Black Coast reveal a complex deformational history (Storey and others, 1987); components of normal, reverse, dextral, and sinistral movement are all present. These sheared rocks may be as old as Late Jurassic, although McGibbon and Wever (in press) inferred a Late Cretaceous age for both the undated alkalic gabbros and the period of shearing.

\section{OPENING OF THE WEDDELL SEA}

The Weddell Sea began to form during the breakup of Gondwanaland, beginning with rifting in the Middle Jurassic (Ford and Kistler, 1980) and followed by seafloor spreading starting about $165 \mathrm{Ma}$ (late Middle Jurassic; LaBrecque, 1986). Relative to modern coordinates, the rift axis was east-west, as indicated by linear magnetic anomalies. The present edge of the continental slope, south of which is unextended continental crust, is at about $74^{\circ} \mathrm{S}$. (Kristoffersen and Haugland, 1986).

The west boundary of the opening Weddell Sea is inferred to have been a north-striking, right-lateral transform fault (Barker and Griffiths, 1977), which we call the Weddell fault system (fig. 24). The Weddell fault system probably was initially part of a Mesozoic rift that extended the length of the Transantarctic Mountains, separating East and West Antarctica (Ford and
Kistler, 1980), and named the Transantarctic rift system by Schmidt and Rowley (1986). Eastern parts of the rift system in the Weddell Sea were identified by Kristoffersen and Hinz (in press). During opening of the Weddell Sea, West Antarctica may have moved about $500-1,000 \mathrm{~km}$ right laterally along faults of the Transantarctic rift system (Schmidt and Rowley, 1986). Opening of the Weddell Sea probably ceased by the end of the Cretaceous or early Cenozoic time (LaBrecque and Barker, 1981; Barker and Lonsdale, in press).

The Latady Formation, as well as the presumed correlative Mount Hill Formation to the north, were deposited concurrently with early stages of opening of the Weddell Sea (fig. 4), although the east side of the Latady-Mount Hill basin was underlain by continental crust (fig. 24). In fact, if the model for right-lateral movement along the Weddell fault system is correct, then most of the Antarctic Peninsula was backed to the east by continental crust at least until latest Middle Jurassic time.

Modern analogues exist for the Weddell fault system and its relationship to an adjacent magmatic arc. For example, the Sumatra fault in Indonesia is a major leftlateral fault that runs the length of the island of Sumatra, which is part of the East Indian Sunda arc (Hamilton, 1987). The Sumatra fault is within or near the axis of the magmatic arc and is due to oblique subduction along the Sunda trench.

\section{ORIGIN OF THE PALMER LAND DEFORMATIONAL EVENT}

The origin is enigmatic for the Late Jurassic to Early Cretaceous period of deformation (the Palmer Land deformational event of Kellogg and Rowley, in press). Three origins are possible. The first two possibilities involve collision of the magmatic arc with another crustal block. The third possibility, which seems preferable to us, involves gravitational spreading and east- to southeast-directed thrusting off the thickened magmatic arc.

Firstly, the deformation may be related to the Early Cretaceous main-phase Rangitata orogeny of New Zealand (Bradshaw and others, 1981; Cooper and others, 1982; Kellogg and Rowley, in press), during which time New Zealand, including the Campbell Plateau, were attached to the Marie Byrd Land coast (Cooper and others, 1982; Barker, 1982). In New Zealand, deformational, metamorphic, and plutonic events of the Rangitata orogeny have been related to the suturing of two tectonostratigraphic terranes-the Torlesse terrane (containing a thick clastic sequence) and a terrane consisting of a continental crustal block with a magmatic-arc 


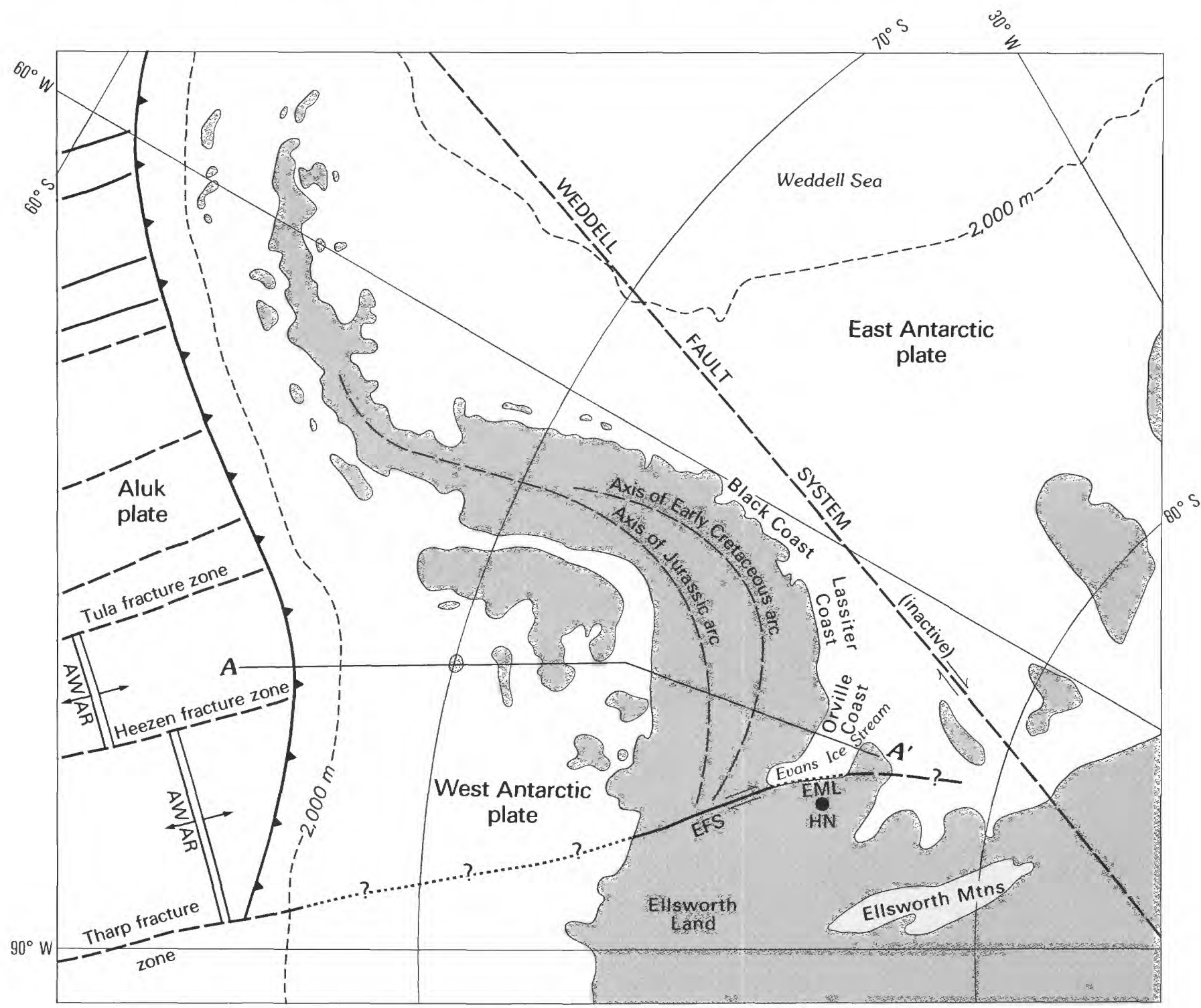

\section{EXPLANATION}

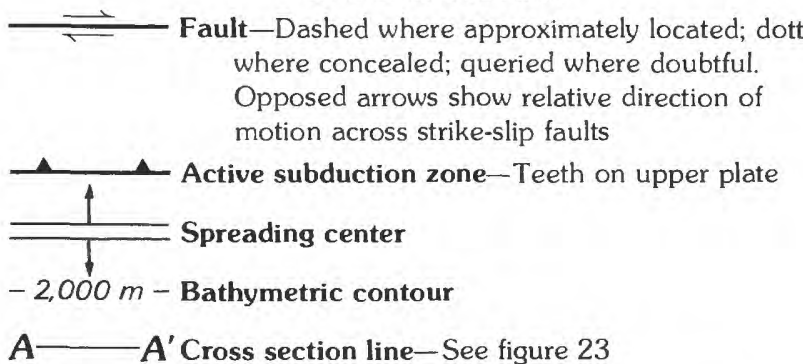

FIGURE 24.-Hypothetical plate configuration of the Antarctic Peninsula area during the Late Cretaceous and early Tertiary, based in part on Kellogg (1980), Barker (1982), LaBrecque (1986), and Schmidt and Rowley (1986). The modern shoreline configuration (shaded) is shown for reference. AWAR, Aluk-West Antarctic ridge; EFS, Ellsworth fault system; EML (along dotted line), Evans Ice Stream magnetic lineament (Garrett, in press); HN, Haag Nunataks.

margin (Bradshaw and others, 1981). The Rangitata orogeny has been related to an Early Cretaceous period of deformation and plutonism also noted in Marie Byrd
Land (Cooper and others, 1982). The Early Cretaceous orogenic belt in Marie Byrd Land is part of the same ("Andean") orogenic belt as in the southern Antarctic 
Peninsula, so it seems plausible that the effects of the Rangitata orogeny may have extended as far as the southern peninsula. Early Cretaceous deformation does, in fact, decrease northward along the peninsula, generally away from Marie Byrd Land; in the northern peninsula, there is little evidence for deformation of this age (Thomson and Pankhurst, 1983).

Secondly, the Palmer Land deformational event may have been due to collision of the Antarctic Peninsula magmatic arc with a block of continental lithosphere containing the Haag Nunataks (fig. 24) that now lies to the south of the Antarctic Peninsula (Rowley and others, 1983); the Haag Nunataks are underlain by Precanibrian gneiss, clearly of continental affinity (Garrett and others, 1987). Although such a collision should thicken the crust, gravity and magnetic modeling indicate that the crust is not significantly thickened across the region to the south of the Orville Coast (Behrendt, 1964). There is a sharp magnetic lineament, however, aligned northwest along and parallel to the Evans Ice Stream (fig. 24). The magnetic lineament separates a southwestern area of sharp, shortwavelength anomalies, apparently underlain by dikeinjected Precambrian crust, from a northeastern area of subdued, longer wavelength anomalies (Garrett, in press), and could be an expression of a major crustal suture.

Thirdly (and favored by us), the folds and thrusts of the southern Antarctic Pensula may be part of a foldand-thrust belt, such as formed elsewhere in the world (for example, Boyer and Elliott, 1982), although observed thrusts are minor and rare in the Orville Coast. The style of folding suggests approximately 50 percent horizontal shortening of the Latady Formation. As geophysical evidence indicates that the crust under the region has not been thickened (Behrendt, 1964), it seems unlikely that the entire lithosphere has been similarly shortened. The only reasonable way to account for horizontal shortening of the Latady Formation is to have a regional décollement underlying the region. Thrust imbricates would overlie such a décollement, so their presence also seems likely.

Foreland folding and thrusting may be due to gravitational spreading of thrust sheets off crust thickened and isostatically elevated by arc magmatism during lengthy subduction (Hamilton, 1985). Spreading does not involve crustal compression or horizontal shortening of the middle or lower crust, as might occur during a collisional event, although compression would be expected in the gravitationally spreading upper crustal rocks. Spreading involves the development of a regional décollement, above which thrust splays imbricate rock sequences. Displacement along the décollement increases toward the axis of the arc, eventually disappearing into a zone of plastic deformation at middle crustal levels. The few possible thrusts observed in the Hauberg and Wilkins Mountains would, therefore, be part of a system of larger, probably mostly hidden thrusts that may exist in the region.

\section{LASSITER COAST INTRUSIVE SUITE}

Compression across the Antarctic Peninsula waned after the Palmer Land deformational event but continued weakly until at least 100-95 Ma during emplacement of the Lassiter Coast Intrusive Suite. Plutons of the suite lie in a belt parallel to the axis of the peninsula, southeast and south of the axis of inferred Middle to Late Jurassic arc volcanism (Vennum and Rowley, 1986). This more southeasterly position may be due to migration with time of the axis of magmatic activity toward the back-arc basin; this in turn is probably related to the Cretaceous episode of world-wide rapid sea-floor spreading and a flattening of the subducting slab beneath the Pacific side of the Antarctic Peninsula (Larson and Pitman, 1972). The plutons probably lie above the approximately $100-\mathrm{km}$-deep position of the subducting slab, where partial melting results from increased water produced by dehydration reactions (Hamilton, 1981).

\section{SOUTHERN TECTONIC BOUNDARY OF THE ORVILLE COAST}

Geologic and geophysical features in the mostly icecovered region south of the Orville Coast and north of the Ellsworth Mountains suggest that the Latady basin was bounded on its south side by extended crust of the Gondwana craton. The southern tectonic margin of the Antarctic Peninsula forms a 1-km-high, sub-ice, dissected escarpment, down to the south, approximately parallel to and about $10 \mathrm{~km}$ south of the Orville Coast shoreline (Bentley and Clough, 1972; Garrett and others, 1987). South of this escarpment, graben-like structures between the Orville Coast and the Ellsworth Mountains have been noted by numerous investigators (Masolov and others, 1981; Doake and others, 1983; Garrett and others, 1987). Storey (in press) used the term "chocolate-tablet boudinage" to describe such regions in West Antarctica that consist of extended and transcurrently faulted, crustally thinned zones surrounding thicker, undeformed crustal blocks.

The prominent escarpment along the Orville Coast shoreline probably represents a major rifted margin that may be the locus of at least some strike-slip movement associated with the Ellsworth fault system. Small, high-angle faults noted in the Orville Coast and eastern Ellsworth Land (fig. 20) cut both sedimentary and 
plutonic rocks and are approximately parallel to and have the same sense of right-lateral movement as the Ellsworth fault system. For these reasons, Kellogg and Rowley (in press) suggested that these small faults may be satellitic to the Ellsworth fault system. Kellogg and Rowley (in press) also suggested that the Ellsworth fault system may be a right-lateral continuation of the Tharp fracture zone (fig. 24) (Barker, 1982), which formed about $85 \mathrm{Ma}$ during the initial rifting of the Campbell Plateau margin of the New Zealand block away from Marie Byrd Land; movement along the Tharp fracture zone ceased about $50 \mathrm{Ma}$ when the Aluk-West Antarctic ridge intersected the subduction zone (Barker, 1982). Herron and Tucholke (1976) had also proposed that a rightlateral transform south of the Antarctic Peninsula was continuous with an unnamed transform fault that offsets the Aluk-West Antarctic ridge.

The major north-northwest-trending magnetic discontinuity along the west side of Evans Ice Stream also marks a 1-km-high sub-ice escarpment that may be a boundary between extended Precambrian crust to the southwest, similar to that found at Haag Nunataks (Garrett and others, 1987), and a thick sequence of sedimentary rocks of the Latady basin to the northeast. This prominent magnetic boundary is in contrast to the very subdued anomalies associated with the major topographic escarpment along the Orville Coast shoreline. The magnetic and topographic boundary may be an expression of a prominent strand of the Ellsworth fault system (fig. 24).

Strike-slip movement along the Ellsworth fault system could not have been large. Paleomagnetic data indicate that the Antarctic Peninsula has remained essentially fixed relative to East Antarctica since middle Cretaceous time (Watts and other, 1984). Furthermore, the Antarctic Peninsula and the part of Ellsworth Land to the south have remained fixed, within the limits of uncertainty of the paleomagnetic data at the 95-percent confidence level, since the Middle Jurassic (Longshaw and Griffiths, 1983; Grunow and others, 1987).

Drag along the Ellsworth fault system may be responsible for clockwise rotations of paleomagnetic vectors by as much as about $60^{\circ}$ in the Sweeney and Hauberg Mountains. The rotation mechanism may have been ductile (oroclinal bending), brittle (fault-block movements), or some combination of the two.

\section{TERTIARY EXTENSION: UPLIFT, BLOCK FAULTING, AND ALKALIC VOLGANISM}

Laudon (1972, p. 220) inferred that a lower Tertiary erosion surface in the southern Antarctic Peninsula and eastern Ellsworth Land was "arched, or tilted and disrupted by block faulting in the late Tertiary." Although the higher elevations toward the axis of the peninsula (as much as $3,000 \mathrm{~m}$ above sea level) and the existence of deep, linear, ice-filled basins (Behrendt, 1964) indicate that arching and block faulting have occurred in this area, the existence of an Upper Cretaceous or lower Tertiary erosion surface has yet to be demonstrated.

The trends in both the shape and structural fabric of McCaw Ridge and the Hauberg, Wilkins, and Sweeney Mountains are parallel to the coastline. Seismicreflection and gravity data define rough sub-ice topography, including valleys nearly $1,000 \mathrm{~m}$ below sea level (Behrendt, 1964). High-angle faults parallel to the structural fabric have not been seen, although the presence of upper Tertiary alkalic olivine basalt in the Merrick Mountains (dated at $6 \mathrm{Ma}$; Halpern, 1971) and Henry Nunataks (Rowley and others, in press) indicates that the southern Antarctic Peninsula marks the eastern limit of a zone of rift-related volcanism that extends across West Antarctica from Marie Byrd Land (LeMasurier and Wade, 1976).

\section{CONCLUSIONS}

The structural features of the Orville Coast and eastern Ellsworth Land are consistent with the following concepts:

1. The Latady Formation was deposited in a back-arc basin behind a Middle and Late Jurassic magmatic arc.

2. The Latady basin, at the time of its formation, was (and still is) backed to the south and east by crystalline crust that is as old as Precambrian.

3. A Late Jurassic to Early Cretaceous period of folding and thrust faulting (Palmer Land deformational event) may be related to gravitational spreading toward the back arc of an elevated crust thickened by a developing magmatic arc. Gravitational spreading involved the development of a regional décollement. Alternatively, deformation may have been due to collision of the Antarctic Peninsula magmatic arc with a continental block. Two possibilities for such an arc-continent collision are (a) the convergence of crustal blocks that might have caused the Rangitata orogeny of New Zealand at the time that New Zealand was still attached to Antarctica, or (b) the collision of the southern Antarctic Peninsula with a crustal block to the south of the present Orville Coast. Collision involved lithospheric shortening without necessarily the development of a regional décollement. 
4. Stresses across the Antarctic Peninsula associated with the Palmer Land deformational event lingered until at least 100-95 Ma during the intrusion of plutons of the Lassiter Coast Intrusive Suite.

5. Copper mineralization, such as found in the Sky-Hi Nunataks, is probably related to hydrothermal fluids, generated during late stages of plutonism, that ascended fractures parallel to the extensionjoint direction, perpendicular to fold axes, in the Latady Formation.

6. The southern Antarctic Peninsula is bounded on the east by a north-trending, right-lateral transform fault, the Weddell fault system, which is part of the Transantarctic rift system of Schmidt and Rowley (1986). The fault was active during opening of the Weddell Sea basin, starting about $165 \mathrm{Ma}$.

7. Small-displacement, high-angle faults are approximately parallel to a right-lateral transform, the Ellsworth fault system, which lies along the south edge of the peninsula. The Ellsworth fault system may be a continuation of the Tharp fracture zone in the southeast Pacific, which ceased activity about $50 \mathrm{Ma}$ when the Aluk-West Antarctic spreading center intersected the trench on the Pacific side of the peninsula.

8. The origin of the eastern Ellsworth Land orocline may be due, at least in part, to drag along the rightlateral Ellsworth fault system, an idea supported by about $60^{\circ}$ clockwise rotation of paleomagnetic directions from the Sweeney and Hauberg Mountains. The rotation mechanism is unknown, but may have been by ductile bending, fault-block rotation, or a combination of the two.

9. The formation of an Upper Cretaceous or lower Tertiary erosion surface across the southern peninsula remains equivocal, although it appears that the region was arched and block faulted. The axis of the arch and the strike of major, sub-ice faults bounding tectonic blocks are both parallel to the shape of the peninsula.

10. The alkalic nature of upper Tertiary olivine-phyric basaltic lava flows in the Merrick Mountains and Henry Nunataks reflects development of the eastern end of a rift system that extends into Marie Byrd Land.

\section{REFERENCES CITED}

Barker, P.F., 1982, The Cenozoic subduction history of the Pacific margin of the Antarctic Peninsula-Ridge crest-trench interactions: Journal of the Geological Society of London, v. 139, p. 787-801.
Barker, P.F., and Griffiths, D.H., 1977, Towards a more certain reconstruction of Gondwanaland: Philosophical Transactions of the Royal Society of London, ser. B, v. 279, p. 143-159.

Barker P.F., and Lonsdale, M.J., in press, A multichannel seismic profile across the Weddell Sea margin of the Antarctic PeninsulaRegional tectonic implications, in Thomson, M.R.A., ed., Fifth International Symposium on Antarctic Earth Sciences, Cambridge, England, August 23-28, 1987.

Behrendt, J.C., 1964, The crustal geology of Ellsworth Land and southern Antarctic Peninsula from gravity and magnetic anomalies: Journal of Geophysical Research, v. 69, p. 2047-2063.

Bentley, C.R., and Clough, J.W., 1972, Seismic refraction shooting in Ellsworth Land and Dronning Maud Land, in Adie, R.J., ed., Antarctic geology and geophysics: Osla, Norway, Universitetsforlaget, p. 169-172.

Boyer, S.E., and Elliott, David, 1982, Thrust systems: American Association of Petroleum Geologists Bulletin, v. 66, p. 1196-1230.

Bradshaw, J.D., Adams, C.J., and Andrews, P.B., 1981, Carboniferous to Cretaceous on the Pacific margin of Gondwana-The Rangitata phase of New Zealand, in Cresswell, M.M., and Vella, P., eds., Gondwana Five: Fifth International Gondwana Symposium, Wellington, New Zealand, A.A. Balkema, p. 217-222.

Carey, S.W., 1958, A tectonic approach to continental drift, in Carey, S.W., ed., Continental drift-A symposium: Hobart, Australia, University of Tasmania, p. 177-355.

Cooper, R.A., Landis, C.A., LeMasurier, W.E., and Speden, I.G., 1982, Geological history and regional patterns in New Zealand and West Antarctica-Their paleotectonic and paleogeographic significance, in Craddock, Campbell, ed., Antarctic geoscience: Madison, Wis., University of Wisconsin Press, p. 43-53.

Dalziel, I.W.D., and Elliot, D.H., 1982, West Antarctica-Problem child of Gondwanaland: Tectonics, v. 1, p. 3-9.

Dalziel, I.W.D., Garrett, S.W., Grunow, A.M., Pankhurst, R.J., Storey, B.C., and Vennum, W.R., 1987, The Ellsworth-Whitmore crustal block-Its role in the tectonic evolution of West Antarctica, in McKenzie, G.D., ed., Gondwana six-Structure, tectonics, and geophysics: Washington, D.C., American Geophysical Union, Geophysical Monograph 40, p. 109-115.

Doake, C.S.M., Crabtree, R.D., and Dalziel, I.W.D., 1983, Subglacial morphology between Ellsworth Mountains and Antarctic PeninsulaNew data and tectonic significance, in Oliver, R.L., James, P.R., and Jago, J.B., eds., Antarctic earth science: Australian Academy of Science and Cambridge University Press, p. 270-273.

Farrar, Edward, McBride, S.L., and Rowley, P.D., 1982, Ages and tectonic implications of Andean plutonism in the southern Antarctic Peninsula, in Craddock, Campbell, ed., Antarctic geoscience: Madison, Wis., University of Wisconsin Press, p. 349-356.

Ford, A.B., 1972, Fit of Gondwana continents-Drift reconstructions from the Antarctic continental viewpoint: 24th International Geological Congress, Montreal, Canada, section 3, p. 113-121.

Ford, A.B., and Kistler, R.W., 1980, K-Ar age, composition, and origin of Mesozoic mafic rocks related to Ferrar Group, Pensacola Mountains, Antarctica: New Zealand Journal of Geology and Geophysics, v. 23, p. 371-390.

Garrett, S.W., in press, Aeromagnetic studies of crustal blocks in West Antarctica-A review, in Thomson, M.R.A., ed., Fifth International Symposium on Antarctic Earth Sciences, Cambridge, England, August 23-28, 1987.

Garrett, S.W., Herrod, L.D.B., and Mantripp, D.R., 1987, Crustal structure of the area around Haag Nunataks, West Antarctica-New aeromagnetic and bedrock elevation data, in McKenzie, G.D., ed., Gondwana Six-Structure, tectonics, and geophysics: Washington, D.C., American Geophysical Union, Geophysical Monograph 40, p. 109-115. 
Grunow, A.M., Dalziel, I.W.D., and Kent, D.V., 1987, EllsworthWhitmore Mountains crustal block, western Antarctica-New paleomagnetic results and their tectonic significance, in McKenzie, G.D., ed, Gondwana Six-Structure, tectonics, and geophysics: Washington, D.C., American Geophysical Union, Geophysical Monograph 40, p. 161-171.

Halpern, Martin, 1967, Rubidium-strontium age measurement of plutonic igneous rocks in eastern Ellsworth Land and northern Antarctic Peninsula, Antarctica: Journal of Geophysical Research, v. 72 , p. $5133-5142$.

1971, Evidence for Gondwanaland from a review of West Antarctic radiometric ages, in Quam, L.O., ed., Research in the Antarctic: American Academy for the Advancement of Science, p. 717-730.

Hamilton, Warren, 1981, Crustal evolution by arc magmatism: Philosophical Transactions of the Royal Society of London, ser. A, v. 301 , p. $279-291$.

1985, Subduction, magmatic arcs, and foreland deformation, in Howell, D.G., ed., Tectonostratigraphic terranes: Circumpacific Council for Energy and Mineral Resources, p. 259-262.

1987, Convergent-plate tectonics viewed from the Indonesian region, in Sengor, A.M.C., ed., Tectonic evolution of the Tethyan domain: Amsterdam, The Netherlands, Reidel Press, p. 1-44.

Herron, E.M., and Tucholke, B.E., 1976, Sea-floor magnetic patterns and basement structures in the southeastern Pacific, in Hollister, C.D., Craddock, Campbell, and others, eds., Initial reports of the Deep Sea Drilling Project, v. 35: U.S. Government Printing Office, p. 263-278.

Kellogg, K.S., 1979, Structural geology of Orville Coast and eastern Ellsworth Land: Antarctic Journal of the United States, v. 14, no. 5 , p. 19-21.

1980, Paleomagnetic evidence for oroclinal bending of the southern Antarctic Peninsula: Geological Society of America Bulletin, v. 91, p. 414-420.

Kellogg, K.S., and Reynolds, R.L., 1978, Paleomagnetic results from the Lassiter Coast, Antarctica, and a test for oroclinal bending of the Antarctic Peninsula: Journal of Geophysical Research, v. 83 , p. $2293-2299$.

Kellogg, K.S., and Rowley, P.D., 1974, Structural geology of the Lassiter Coast: Antarctic Journal of the United States, v. 9, p. 224-225. in press, Tectonic evolution of southeastern Antarctic Peninsula, in Thomson, M.R.A., ed., Fifth International Symposium on Antarctic Earth Sciences, Cambridge, England, August 23-28, 1987.

Kristoffersen, Yngve, and Haugland, Kristen, 1986, Geophysical evidence for the East Antarctic plate boundary in the Weddell Sea: Nature, v. 322 , no. 6079 , p. $538-541$.

Kristoffersen, Yngve, and Hinz, Karl, in press, Complexities of the East-Antarctic Gondwana plate boundary in the Weddell Sea, in Thomson, M.R.A., ed., Fifth International Symposium on Antarctic Earth Sciences, Cambridge, England, August 23-28, 1987.

LaBrecque, J.L., 1986, South Atlantic Ocean and adjacent Antarctic continental margin: Ocean Margin Drilling Program, Regional Atlas Series, Atlas 13, Woods Hole, Mass., Marine Science International, 21 sheets.

LaBrecque, J.L., and Barker, P.F., 1981, The age of the Weddell Basin: Nature, v. 290, p. 489-492.

Larson, R.L., and Pitman, W.C., 1972, World-wide correlation of Mesozoic magnetic anomalies and its implications: Geological Society of America Bulletin, v. 83, p. 3645-3662.

Laudon, T.S., 1972, Stratigraphy of eastern Ellsworth Land, in Adie, R.J., ed., Antarctic geology and geophysics: Oslo, Norway, Universitetsforlaget, p. 215-223.

Laudon, T.S., Lackey, L.L., Quilty, P.G., and Otway, P.M., 1970, Geology of eastern Ellsworth Land, in Bushnell, N.C., and
Craddock, Campbell, eds., Geologic maps of Antarctica: American Geographic Society, Antarctic Map Folio Series, Folio 12, Plate III, scale $1: 1,000,000$.

Laudon, T.S., Thomson, M.R.A., Williams, P.L., Milliken, K.L., Rowley, P.D., and Boyles, J.M., 1983, The Jurassic Latady Formation, southern Antarctic Peninsula, in Oliver, R.L., James, P.R., and Jago, J.B., eds., Antarctic earth science: Australian Academy of Science and Cambridge University Press, p. 308-319.

LeMasurier, W.E., and Wade, F.A., 1976, Volcanic history in Marie Byrd Land-Implications with regard to southern hemisphere tectonic reconstructions, in Gonzales-Ferran, Oscar, ed., Andean and Antarctic volcanology problems: Rome, Italy, International Association of Volcanology and Chemistry of the Earth's Interior, p. $398-424$.

Longshaw, S.K., and Griffiths, D.H., 1983, A paleomagnetic study of Jurassic rocks from the Antarctic Peninsula and its implications: Journal of the Geological Society of London, v. 140, p. 945-954.

Masolov, V.N., Kurinin, R.G., and Grikurov, G.E., 1981, Crustal structure and tectonic significance of Antarctic rift zones, in Cresswell, M.M., and Vella, P., eds., Gondwana Five: Fifth International Gondwana Symposium, Wellington, New Zealand, A.A. Balkema, p. 303-309.

McGibbon, K.J., and Wever, H.E., in press, Magnetic evidence for Late Cretaceous back-arc extension in the Black Coast, Palmer Land, in Thomson, M.R.A., ed., Fifth International Symposium on Antarctic Earth Sciences, Cambridge, England, August 23-28, 1987.

Mehnert, H.H., Rowley, P.D., and Schmidt, D.L., 1975, K-Ar ages of plutonic rocks in the Lassiter Coast area, Antarctica: U.S. Geological Survey Journal of Research, v. 3, p. 233-236.

Meneilly, A.W., Harrison, S.M., Piercy, B.A., and Storey, B.C., 1987, Structural evolution of the magmatic arc in northern Palmer Land, Antarctic Peninsula, in McKenzie, G.D., ed., Gondwana SixStructure, tectonics, and geophysics: Washington, D.C., American Geophysical Union, Geophysical Monograph 40, p. 209-219.

Pankhurst, R.J., and Rowley, P.D., in press, Rb-Sr study of Cretaceous plutons from the Orville and Lassiter Coasts, Antarctic Peninsula, in Thomson, M.R.A., ed., Fifth International Symposium on Antarctic Earth Sciences, Cambridge, England, August 23-28, 1987.

Rowley, P.D., 1978, Geologic studies in Orville Coast and eastern Ellsworth Land, Antarctic Peninsula: Antarctic Journal of the United States, v. 13, no. 4, p. 7-9.

Rowley, P.D., Farrar, Edward, Carrara, P.E., Vennum, W.R., and Kellogg, K.S., 1988, Porphyry-type copper deposits and $\mathrm{K}-\mathrm{Ar}$ ages of plutonic rocks of the Orville Coast and eastern Ellsworth Land, Antarctica, in Rowley, P.D., and Vennum, W.R., eds., Studies of the geology and mineral resources of the southern Antarctic Peninsula and eastern Ellsworth Land, Antarctica: U.S. Geological Survey Professional Paper 1351-C, p. 35-49.

Rowley, P.D., Kellogg, K.S., and Vennum, W.R., 1985, Geologic studies in the English Coast, eastern Ellsworth Land: Antarctic Journal of the United States, v. 19, p. 34-36.

Rowley, P.D., Kellogg, K.S., Vennum, W.R., Laudon, T.S., Thomson, J.W., O'Neill, J.M., and Lidke, D.J., in press, Tectonic setting of the English Coast, eastern Ellsworth Land, Antarctica, in Thomson, M.R.A., ed., Fifth International Symposium on Antarctic Earth Sciences, Cambridge, England, August 23-28, 1987.

Rowley, P.D., Schmidt, D.L., and Williams, P.L., 1982, Mount Poster Formation, southern Antarctic Peninsula and eastern Ellsworth Land: Antarctic Journal of the United States, v. 17, p. 38-39.

Rowley, P.D., Storey, B.C., Ford, A.B., and Wever, H.E., 1987, Geology of the central Black Coast, Antarctic Peninsula: Antarctic Journal of the United States, v. 22, no. 5, p. 1-3. 
Rowley, P.D, Vennum, W.R., Kellogg, K.S., Laudon, T.S., Carrara, P.E., Boyles, J.M., and Thomson, M.R.A., 1983, Geology and plate tectonic setting of the Orville Coast and eastern Ellsworth Land, Antarctica, in Oliver, R.L., James, P.R., and Jago, J.B., eds., Antarctic earth science: Australian Academy of Science and Cambridge University Press, p. 345-350.

Rowley, P.D., and Williams, P.L., 1982, Geology of the northern Lassiter Coast and southern Black Coast, Antarctic Peninsula, in Craddock, Campbell, ed., Antarctic geoscience: Madison, Wis., University of Wisconsin Press, p. 339-348.

Rowley, P.D., Williams, P.L., and Schmidt, D.L., 1977, Geology of an Upper Cretaceous copper deposit in the Andean province, Lassiter Coast, Antarctic Peninsula: U.S. Geological Survey Professional Paper 984, $36 \mathrm{p}$.

Schmidt, D.L., and Rowley, P.D., 1986, Continental rifting and transform faulting along the Jurassic Transantarctic rift, Antarctica: Tectonics, v. 5, p. 279-291.

Singleton, D.G., 1980, The geology of the central Black Coast, Palmer Land: British Antarctic Survey Scientific Reports, no. 102, 50 p.

Stanek, K.P., 1987, Beitrag zur geologie der sudichen Lassiter Coast und der ostlichen Orville Coast (Antarktische Halbinsel) [Contribution to the geology of the southern Lassiter Coast and eastern Orville Coast (Antarctic Peninsula)]: Freiberger Forschungshefte, v. C-412, p. 5-50.

Steiger, R.H., and Jäger, E., 1977, Subcommission on geochronologyConvention on the use of decay constants in geo- and cosmochronology: Earth and Planetary Science Letters, v. 36, p. 359-362.

Storey, B.C., in press, West Antarctica crustal fragments within Gondwanaland-New constraints, in Thomson, M.R.A., eds., Fifth International Symposium on Antarctic Earth Sciences, Cambridge, England, August 23-28, 1987.

Storey, B.C., and Garrett, S.W., 1985, Crustal growth of the Antarctic Peninsula by accretion, magmatism, and extension: Geological Magazine, v. 122, p. 5-14.

Storey, B.C., Wever, H.E., Rowley, P.D., and Ford, A.B., 1987, The geology of the central Black Coast, eastern Palmer Land: British Antarctic Survey Bulletin, no. 77, p. 145-155.

Suárez, Manuel, 1976, Plate tectonic models for southern Antarctic Peninsula and its relation to southern Andes: Geology, v. 4, p. 211-214.

Taylor, B.J., Thomson, M.R.A., and Willey, L.E., 1979, The geology of the Ablation Point-Keystone Cliffs area, Alexander Island: British Antarctic Survey Scientific Reports, no. 82, 65 p.
Thomson, M.R.A., 1982, Mesozoic paleogeography of West Antarctica, in Craddock, Campbell, ed., Antarctic geoscience: Madison, Wis., University of Wisconsin Press, p. 331-337.

1983, Late Jurassic ammonites from the Orville Coast, Antarctica, in Oliver, R.L., James, P.R., and Jago, J.B., eds., Antarctic earth science: Australian Academy of Science and Cambridge University Press, p. 328-333.

Thomson, M.R.A., Laudon, T.S., and Boyles, J.M., 1978, Stratigraphical studies in Orville Coast and eastern Ellsworth Land: Antarctic Journal of the United States, v. 13, p. $9-10$.

Thomson, M.R.A., and Pankhurst, R.J., 1983, Age of post-Gondwanian calc-alkaline volcanism in the Antarctic Peninsula, in Oliver, R.L., James, P.R., and Jago, J.B., eds., Antarctic earth science: Australian Academy of Science and Cambridge University Press, p. 328-333.

Tranter, T.H., 1986, The LeMay Group of central Alexander Island: British Antarctic Survey Bulletin, no. 71, p. 57-67.

in press, Accretion and subduction processes along the Pacific margin of Gondwana, central Alexander Island, in Thomson, M.R.A., ed., Fifth International Symposium on Antarctic Earth Sciences, Cambridge, England, August 23-28, 1987.

Vennum, W.R., and Laudon, T.S., 1988, Igneous petrology of the Merrick Mountains, eastern Ellsworth Land, Antarctica, in Rowley, P.D., and Vennum, W.R., eds., Studies of the geology and mineral resources of the southern Antarctic Peninsula and eastern Ellsworth Land, Antarctica: U.S. Geological Survey Professional Paper 1351-B, p. 21-34.

Vennum, W.R., and Rowley, P.D., 1986, Reconnaissance geochemistry of the Lassiter Coast Intrusive Suite, southern Antarctic Peninsula: Geological Society of America Bulletin, v. 97, p. 1521-1533.

Watts, D.R., Watts, G.C., and Bramall, A.M., 1984, Cretaceous and early Tertiary paleomagnetic results for the Antarctic Peninsula: Tectonics, v. 3, p. 333-346.

Weissel, J.K., Hayes, D.E., and Herron, E.M., 1977, Plate tectonic synthesis-The displacements between Antarctica, New Zealand, and Antarctica since the Late Cretaceous: Marine Geology, v. 25, p. 231-277.

Williams, P.L., Schmidt, D.L., Plummer, C.C., and Brown, L.E., 1972, Geology of the Lassiter Coast area, Antarctic PeninsulaPreliminary report, in Adie, R.J., ed., Antarctic geology and geophysics: Oslo, Norway, Universitetsforlaget, p. 143-148. 